\title{
1 Global assessment and mapping of ecological vulnerability to
} 2 wildfires

3 Fátima Arrogante-Funes ${ }^{1}$, Inmaculada Aguado ${ }^{1}$ and Emilio Chuvieco ${ }^{1}$

4 ' ${ }^{1}$ Universidad de Alcalá, Facultad de Filosofía y Letras, Departamento de Geografía, Geología y Medio Ambiente, 5 Área de Geografía, GITA, C/Colegios 2, 2881, Alcalá de Henares, Madrid, España.

Correspondence to: Fátima Arrogante-Funes (fatima.arrogante@uah.es)

\begin{abstract}
Fire is a natural phenomenon that has played a critical role in transforming the environment and maintaining biodiversity at a global scale. However, the plants in some habitats have not developed strategies for recovery from fire or have not adapted to the changes taking place in their fire regimes. Maps showing ecological vulnerability to fires could contribute to environmental management policies in the face of global change scenarios. The main objective of this study is to assess and map ecological vulnerability to fires on a global scale. To this end, we created ecological value and post-fire regeneration delay indices on the basis of existing global databases. Two ecological value indices were identified: biological distinction and conservation status. For the post-fire regeneration delay index, various factors were taken into account, including the type of fire regime, the increase in the frequency and intensity of forest fires and the potential soil erosion they can cause. These indices were combined by means of a qualitative cross-tabulation to create a new index evaluating ecological vulnerability to fire. The results showed that global ecological value could be reduced by as much as $50 \%$, due to fire perturbation of ecosystems that are poorly adapted to it. The terrestrial biomes most affected are the tropical and subtropical moist broadleaf forest; tundra; mangroves; tropical and subtropical coniferous forests; and tropical and subtropical dry broadleaf forests.
\end{abstract}

\section{Introduction}

Fire is a natural phenomenon that has played an important role in the transformation of the environment and the maintenance of biodiversity on a global scale. It can have numerous positive and negative impacts. Most of the world's terrestrial habitats where fires occur depend on them for ecological sustainability. (Kirkman et al., 2001; Midgley \& Bond, 2015). Fire can affect the distribution of habitats, carbon and nutrient fluxes, and the waterholding properties of soils (Bowman et al., 2009). In habitats that are adapted to and even dependent on fire exclusion policies, this can result in a decrease in biodiversity (Guyette et al., 2002). In addition, the absence of fire results in increases in fuel loads (Bond et al., 2005), which frequently augment the risk of catastrophic fires over time. Fire has also been and continues to be used by humans as a crucial tool for managing terrestrial ecosystems, producing cultural landscapes that also benefit ecological health (Caprio \& Graber, 2000; Guyette et al., 2002).

On the other hand, there are some habitats, such as moist tropical forests, that have never adapted to fires. The introduction of fire by humans can lead to an irreparable loss of their structure and composition (Cochrane \& Laurance, 2002). Even in fire-adapted areas such as the Mediterranean ecosystems, recent human and climaterelated changes in fire regimes are having negative impacts on the functioning of ecosystems (Bajocco et al., 2011; Midgley \& Bond, 2015). The increasing frequency and intensity of fires can have negative impacts on forest 
masses and landscapes, human life, infrastructures and ecosystem services and wildlife; and can cause changes in regeneration dynamics, hydrological regimes and air quality, among other environmental consequences on a global scale (Alcasena et al., 2016; Barrio et al., 2011; Buhk et al., 2007; Díaz-Delgado et al., 2002; Flannigan et al., 2009; Hobson \& Schieck, 1999; Moreira et al., 2011; Scott \& Van Wyk, 1990). As a result of this process of change, forest fires have become one of the main environmental problems today at both global and local levels. This means that fires must be included in global and regional assessments of vulnerability to global change (Houghton et al., 2001; Lindner et al., 2010). Furthermore, fire risk assessment should be carried out spatially in order to design and implement prevention strategies that enable the conservation of the ecological value of ecosystems and landscapes. When fires happen, assessments of this kind can also be useful for implementing postfire strategies to bring about the recovery of pre-fire ecological values and cultural and socioeconomic assets (Aretano et al., 2015; Chuvieco et al., 2010). In terms of natural hazards terminology, spatially measured fire risk is a combination of 'danger' and 'vulnerability'. 'Danger' is defined as the probability of fire occurring in a given place and time, while vulnerability refers to the potential damage that fire could cause to this place (Chuvieco et al., 2007).

The concept of vulnerability has been studied and applied at different spatial scales and in a wide range of disciplines, in both social and natural studies (Abson et al., 2012; Berry et al., 2006; Cinner et al., 2012; Cutter et al., 2003; Moreno \& Becken, 2009).

Vulnerability has many different definitions. For example, the definition proposed by the IPCC (2007) is based on the assumption that an ecosystem cannot cope with a disturbing event (earthquake, fire, flood, etc.) and is therefore vulnerable to it. In order to assess where adaptation actions may be necessary and beneficial, vulnerability assessment must analyse the factors that determine the potential for damage from exogenous threats, as well as the endogenous adaptive capacity of the ecosystem (Preston et al., 2011).

An ideal assessment of ecological vulnerability must therefore take into account the biotic and abiotic aspects of the environment (e.g. species richness, conservation status of the ecosystems), the relationship between them (e.g. ecosystem functionality) (Ippolito et al., 2010), as well as any temporal and spatial pressures (e.g. landscape fragmentation) (Williams \& Kapustka, 2000). An integrated approach to vulnerability can therefore be achieved by developing different indices that characterize the biodiversity and ecological quality of the environment, its exposure to fire and its capacity to adapt and regenerate once a fire has been extinguished.

Some attempts to assess vulnerability do not take all these elements into account (Turner et al., 2003). The study by Duguy et al., (2012) characterized ecological vulnerability using the species richness measurement, at a local scale, in Mediterranean forests. In research in southern Italy, also on a local scale, Aretano et al., (2015) proposed an ecological sensitivity index covering unique habitats, susceptibility to fire and regeneration capacity, but did not evaluate soil erosion after disturbance. At the regional level, Chuvieco et al., (2010) studied ecological vulnerability in line with the degree of protection of the area, reviewing the different legal forms for the official protection of ecosystems, homogeneous landscape units and land uses. This approach focused more on landscape ecology than on species biodiversity, in which adaptation to fire is considered through the strategies developed by plants in response to fire. In other research, such as the study by González, Kolehmainen, \& Pukkala, (2007), the vulnerability of the ecosystem to fire was evaluated by a group of experts who were provided with images and data on forest metrics measured in the field, together with aerial photographs. Regional studies have been conducted to evaluate the effects of fire on soils and post-fire dynamics in ecosystems (Duguy \& Vallejo, 2008; 
Giovannini \& Lucchesi, 1997). The first global analysis of wildfire vulnerability was done by Chuvieco et al. (2014), who estimated the standing ecological value of ecosystems from biodiversity data, their state of conservation and the fragmentation of the landscape. The delay in the post-fire regeneration of vegetation was estimated by assessing their adaptation to fire and potential soil erosion. Adaptation to fire was analysed by comparing the real land cover with fire simulations based on the dynamic global vegetation model.

In this paper, we carry out a systematic assessment of ecological vulnerability to wildfires on a global scale using an index that combines the two main components of vulnerability, namely the ecological value of ecosystems and the delay in post-fire regeneration. The novelty of this approach lies in the characterization of structural biodiversity from the point of view of its exceptionality, while also assessing biodiversity in terms of ecosystem functionality. In addition, in this study, rather than approaching the post-fire regeneration of forests as part of a static, immutable system, as most previous researchers have done, we view these strategies within the dynamic context of changing fire regimes. This study will be carried out on a global scale so as to enable us to tackle the planetary ecosystem as a whole, unrestricted by governmental or geographic borders. In this way, this research could become an essential tool for decision-making about resource management and nature conservation across the globe.

\section{Materials and methods}

\subsection{Conceptual framework}

In order to develop the Ecological Vulnerability Index proposed in this study, our first task was to estimate the ecological value of the environment and its regeneration capacity after fire disturbance. To do so, we had to process the different input variables and devise a way to integrate them into the index (Table 1). 
Table 1: Conceptual framework and diagram for the Ecological Vulnerability Index, and reference sources

\begin{tabular}{|c|c|c|c|c|c|}
\hline & & Factor & Input Variables & Source & Method \\
\hline & & Taxonomic Rarity & $\begin{array}{l}\text { Vertebrate and } \\
\text { Vascular Plant }\end{array}$ & $\begin{array}{l}\text { Kier et al., (2009); } \\
\text { World Wildlife }\end{array}$ & $\begin{array}{l}\text { Endemism Ratio to Total } \\
\text { Species }\end{array}$ \\
\hline & Biological & Species Richness & $\begin{array}{l}\text { Number of Vertebrates } \\
\text { and Vascular Plants }\end{array}$ & $\begin{array}{l}\text { Kier et al., (2005); } \\
\text { World Wildlife } \\
\text { Fund, (2006) }\end{array}$ & $\begin{array}{l}\text { Species Total Normalized } \\
\text { by Area }\end{array}$ \\
\hline & $\begin{array}{l}\text { Distinction } \\
\text { Index }\end{array}$ & Functional Diversity & $\begin{array}{l}\text { Specific Leaf Area, Leaf } \\
\text { Dry Matter Content, } \\
\text { Leaf Nitrogen Content, } \\
\text { Leaf Phosphorus } \\
\text { Content }\end{array}$ & $\begin{array}{l}\text { Moreno-Martínez } \\
\text { et al., (2018) }\end{array}$ & $\begin{array}{l}\text { Carbon, Nitrogen and } \\
\text { Phosphorous Cycle } \\
\text { Productivity }\end{array}$ \\
\hline Ec & & Unique Habitats & Global 200 Map & $\begin{array}{l}\text { Olson \& Dinerstein, } \\
\text { (2002) }\end{array}$ & $\begin{array}{l}\text { Percentage Unique } \\
\text { Habitats in relation to the } \\
\text { Total by Ecoregion }\end{array}$ \\
\hline Index & & $\begin{array}{l}\text { Unique Preservation } \\
\text { Habitats }\end{array}$ & $\begin{array}{l}35 \text { Priority Places Map, } \\
\text { Red List of Threatened } \\
\text { Species }\end{array}$ & $\begin{array}{l}\text { Burgess et al., } \\
\text { (2014); World } \\
\text { Wildlife Fund, } \\
\text { (2006) }\end{array}$ & $\begin{array}{l}\text { Percentage of Protected } \\
\text { Area, Number of } \\
\text { Threatened Species }\end{array}$ \\
\hline & $\begin{array}{l}\text { Conservation } \\
\text { State Index }\end{array}$ & $\begin{array}{l}\text { Intact Forest } \\
\text { Landscapes Blocks }\end{array}$ & $\begin{array}{l}\text { Intact Forest } \\
\text { Landscapes Maps }\end{array}$ & $\begin{array}{l}\text { Potapov et al., } \\
\text { (2008) }\end{array}$ & $\begin{array}{l}\text { Percentage of Intact } \\
\text { Forest in relation to the } \\
\text { Total Area by Ecoregion }\end{array}$ \\
\hline & & $\begin{array}{l}\text { Degree of } \\
\text { Fragmentation }\end{array}$ & $\begin{array}{l}\text { Fragmentation by } \\
\text { Ecoregion }\end{array}$ & $\begin{array}{l}\text { Hoekstra et al., } \\
\text { (2010) }\end{array}$ & $\begin{array}{l}\text { Homogeneity Percentage } \\
\text { by Ecoregion }\end{array}$ \\
\hline & & & $\begin{array}{l}\text { World Database on } \\
\text { Protected Areas }\end{array}$ & $\begin{array}{l}\text { IUCN \& UNEP- } \\
\text { WCMC, (2020) }\end{array}$ & $\begin{array}{l}\text { Percentage of Protected } \\
\text { Area in relation to the } \\
\text { Total Area by Ecoregion }\end{array}$ \\
\hline & $\begin{array}{l}\text { Potential } \\
\text { Soil Erosion }\end{array}$ & RUSLE & RUSLE Map & $\begin{array}{l}\text { Borrelli et al., } \\
(2017)\end{array}$ & Qualitative Ranges \\
\hline $\begin{array}{l}\text { Regeneration } \\
\text { Delay }\end{array}$ & $\begin{array}{l}\text { Adaptation } \\
\text { to Fire }\end{array}$ & $\begin{array}{l}\text { Fire-regime } \\
\text { Fire-regime } \\
\text { Degradation }\end{array}$ & $\begin{array}{l}\text { Fire-regime Map } \\
\text { Fire Condition Natural } \\
\text { Degradation Map }\end{array}$ & Shlisky et al., (2007) & Qualitative Ranges \\
\hline
\end{tabular}

\subsection{Spatial Unit}

The spatial units used in this study were the terrestrial ecoregions proposed by the World Wildlife Fund (WWF), as corrected in 2017 (Olson et al., 2001). The terrestrial ecoregion concept refers to a land unit large enough to house a set of natural communities composed of different species, dynamics and similar environmental conditions. Thus, ecoregions are a good way to structure ecological and fire information on a global scale, since they are relatively homogeneous in terms of climate and vegetation (Pausas \& Ribeiro, 2017). For this reason, ecoregions are considered a more suitable unit of reference on which to add spatial biological information, compared to other possible units such as grids.

The database is made up of 827 ecoregions distributed in 14 biomes. The ecoregions in which it is impossible for forest fires to occur were excluded, while other areas, such as Antarctica, were excluded due to lack of data. In this way, the number of ecoregions and terrestrial biomes were reduced to 660 and 14, respectively.

\subsection{Burnable Area}

It was necessary to define the burnable area in order to identify areas in which fires are unable to expand. Our assessment of Burnable Area was based on the global Land Cover (LC) dataset produced under the Climate Change Initiative (CCI) program of the European Space Agency (ESA) (www.esa-landcover-cci.org). The CCI-LC map was generated from MERIS-Envisat images acquired at $300 \mathrm{~m}$ between 2008 and 2012. The original product 
includes 22 land covers, which were reclassified to burnable/unburnable covers and then resampled at a resolution of 0.25 degrees.

Ecoregions with burnable areas of $\leq 33 \%$ were removed from further analysis, as they would suffer only marginal impacts of fire. This is because these areas have no vegetation and therefore no fuel to start and spread a fire. This reduced the final number of ecoregions and terrestrial biomes used in our analysis to 647 and 14, respectively (Fig. A1).

\subsection{Representativeness Criteria}

The approach used to establish the ecological value of the different terrestrial ecoregions is based on the concept of representativeness. In this way, each biome is guaranteed to have at least one priority ecoregion, so ensuring, for example, that the ecoregions in the savanna forest biome can also be classified, in addition to the more important moist tropical forests, which would otherwise dominate the list of values due to their high rates of species richness and endemic species (endemisms). This approach is used in ecoregional evaluations that enable comparison between studies (Burgess et al., 2006; Ricketts et al., 1999). The biological values were studied by ecoregion within the biome to which they belong. Then, all the ecoregions with their respective biological values were combined in a map at global level.

\subsection{Ecological Index}

To evaluate the ecological component relative to the ecoregions within each biome, two indices were qualitatively generated and integrated by cross-tabulation: i) biological distinction and ii) conservation status. This approach enables us to characterize structural biodiversity from the point of view of its exceptionality, and in terms of ecosystem functionality (Dinerstein et al., 1995; Ricketts et al., 1999).

\subsubsection{Biological Distinction Index}

Biological distinction is more than just biodiversity at the species level, in that it also covers the diversity of ecological functions and the processes that support structural biodiversity (Ricketts et al., 1999). Specifically, this study is based on taxonomic rarity, species richness, functional diversity, and habitats with a unique evolution.

Taxonomic Rarity and Species Richness. The lists of species and endemisms (i.e. at least $75 \%$ of the taxon occurs in the same place) by ecoregion for mammals, birds, reptiles and amphibians form a dataset that can be gleaned from the literature, distribution databases, and fieldwork carried out by expert taxonomists (WWF, 2006). Likewise, the data relating to diversity and vascular plant endemisms (Kier et al., 2005, 2009) have been used in numerous ecological studies (Freudenberger et al., 2012; Poos, Walker, \& Jackson, 2009).

To find out more about vertebrate species diversity, the total number was obtained by adding up all the vertebrate species belonging to the same ecoregion. The data were then normalized according to land area (Eq. (1)):

$$
S A=S /(A)^{Z}
$$

where SA is the number of species corrected by ecoregion, $\mathrm{S}$ the total number of species, $\mathrm{A}$ is the area in $\mathrm{km}^{2}$ and $\mathrm{Z}$ is the correction factor for continental mainland (value of 0.2) and islands (value 0.25) (Rosenzweig, 1995). As numerous studies show (Burgess et al., 2006; Olson et al., 2001; Ricketts et al., 1999), the behaviour of this data type is associated with the size of the territory, which is why in order to make them comparable we had to apply this method of approximation to the species-area distribution curve. The same process was followed to obtain the 
richness of vascular plant species, except that the data for the total number of species by ecoregion had already been collected.

To assess the absolute taxonomic rarity for vertebrates and vascular plants, the endemism-richness ratio (Eq. (2)) was calculated. This estimates the number of species endemic to the ecoregion as a proportion of its species richness:

$$
R=(\Sigma E / \Sigma S) \quad(2)
$$

where $\mathrm{R}$ is the percentage of endemisms, $\mathrm{E}$ the endemisms and $\mathrm{S}$ the species.

Functional Diversity. The continuous data about Specific Leaf Area (SLA), Leaf Dry Matter Content (LDMC), Leaf Nitrogen Content (LNC) and Leaf Phosphorus Content (LPC) (g x g -1) was provided by Moreno-Martínez et al., (2018) at 500m spatial resolution. It was used as a proxy of Carbon, Nitrogen and Phosphorus cycle productivity.

To obtain the productivity of each cycle, an average figure by ecoregion was estimated. The productivity values were then scaled in a monotonous linear manner increasing from 0 to 100 , so as to enable us to compare productivity between the different ecoregions. Finally, functional diversity was integrated as a sum of the productivity values for the carbon, nitrogen and phosphorus cycle.

The environment is a holistic system, which means that loss of function affects the capacity of the ecosystem to support not only itself, but also its neighbours (Pausas \& Ribeiro, 2017). Ecoregions with high functional diversity values are therefore considered more vulnerable to fires because they provide support for other ecosystems that could also be damaged indirectly by fire in this way.

Unique Habitats. The Global 200 (G200) cartography (Olson \& Dinerstein, 2002) shows the area in square kilometres of habitats with unusual ecological and evolutionary phenomena by ecoregion, which make them irreplaceable (Myers et al., 2010). In this way, 141 terrestrial ecoregions were identified. To assess the G200 cartography, we calculated the ratio between the area occupied by these habitats and the total area of the ecoregion. Integrating the Factors into the Biological Distinction Index. The above factors were integrated into the Biological Distinction Index using the criteria established by Burgess et al., (2006). First, the factors per ecoregion were scaled in a monotonous linear way increasing from 0 to 100 within the biome. The taxonomic rarity scores were given the most weight as they establish the qualitative ranges of the biodiversity through quartiles: Very High, High, Moderate and Low (Table 2). In the case of endemic species, this is because if a fire occurred in one of these ecoregions, the entire species would be wiped out. For the other factors, the first quartiles of species richness and of unique habitats and scores of $>95$ for functional diversity are taken into account when assigning these ecoregions to the exceptional category (Table 2). 
Table 2: Summary of the criteria for assigning ecoregions within the biomes to the different categories.

\begin{tabular}{l|llll}
\cline { 2 - 5 } Categories & \multicolumn{1}{c}{ Endemisms } & \multicolumn{1}{c}{ Species Richness } & Functional Diversity & \multicolumn{1}{c}{$\begin{array}{c}\text { Unique } \\
\text { Habitats }\end{array}$} \\
\hline Very High & $\begin{array}{l}\text { First quartile of total } \\
\text { endemisms within the } \\
\text { biome } \\
\text { Second quartile of total } \\
\text { endemisms within the } \\
\text { biome } \\
\text { Third quartile of total } \\
\text { Moderate }\end{array}$ & $\begin{array}{l}\text { First quartile of } \\
\text { species richness } \\
\text { within the biome } \\
\text { biome }\end{array}$ & $\begin{array}{l}\text { Ecoregions with more } \\
\text { than 95\% productivity }\end{array}$ & $\begin{array}{l}\text { First quartile of } \\
\text { unique habitats }\end{array}$ \\
Low & $\begin{array}{l}\text { Fourth quartile of total } \\
\text { endemisms within the } \\
\text { biome }\end{array}$ & & \\
\hline \hline
\end{tabular}

\subsubsection{Conservation Status Index}

The Conservation Status Index seeks to estimate the current and future capacity of an ecoregion to meet the following biodiversity conservation and quality objectives: maintain populations and communities of viable species, maintain ecological processes, and respond effectively to environmental changes over time. Specifically, this study is based on the preservation of unique habitats, the presence of landscapes that contain intact habitats, the degree of environmental fragmentation and the level of protection they enjoy.

Unique Habitats Preservation. The 35 Priority Places (35PP) cartography, proposed by the WWF, consolidates special conservation areas because they are an extensive and intact representation of unique ecosystems (Burgess et al., 2014). Of these, we maintained the 33 terrestrial ecoregions with a degree of protection and then estimated the ratio between the area occupied by these protected ecosystems and the total area of the ecoregion to which they belonged.

For its part, the Red List of Threatened Species (RL) provides data about the current situation of the biodiversity (WWF, 2006). We maintained the species on this list categorized as: "critically endangered", "endangered" and "vulnerable". These categories were selected because there are common criteria for the management and conservation of the habitats that host these species (Hilton-Taylor, 2000; Mace \& Lande, 1991). We then calculated the total number of threatened species by ecoregion.

Both processed variables were scaled from 0 to 100 in an increasing monotonous linear manner and were added together to obtain the singular habitats preservation factor.

Intact Forest Landscapes Blocks. From an ecological point of view, old-growth forests are of great importance, albeit more structural than functional, in terms of their role in the conservation of most of terrestrial diversity, hosting indigenous populations and contributing enormously to the regulation of the global climate. Outside these blocks, for example in planted forests, characteristics such as the age of the plants or the composition of the mass could not be maintained in such an exceptional way. The Intact Forest Landscapes (IFL) cartography (Potapov et al., 2008) charts the location and extent of the forests and terrestrial ecosystems that remain unaltered by humans, with a minimum mappable unit of $500 \mathrm{~km}^{2}$. The IFL area data was added to the corresponding ecoregions and the area occupied by these forests as a percentage of the total area of the ecoregion was calculated. 
Degree of Fragmentation. Landscape fragmentation mapping by ecoregion is based on the method proposed by Hoekstra et al., (2010). It shows the degree of fragmentation as a percentage, with the highest percentages corresponding to highly degraded or heterogeneous landscapes and the lowest to areas that are unfragmented or homogeneous.

The degree of homogeneity was established by scaling the values for terrestrial ecoregions in a monotonous linear manner reversing the original scale from $0-100$ to $100-0$. The more homogeneous compositions have higher biodiversity ratios (Collinge, 1996), so making them more vulnerable to fire due to the ecological loss that this would cause (Pausas et al., 2003).

Degree of Protection. Protected status, mainly in the form of national parks and reserves, plays an essential role in conservation. These areas are mapped in the World Database on Protected Areas (WDPA), which was generated as part of a project developed by the United Nations Environment Program (UNEP) and by the IUCN, administered by the World Center Conservation Monitoring Committee (WCMC) and UNEP (IUCN \& UNEP-WCMC, 2020). In this study, we only considered the terrestrial protected areas classified under IUCN categories I-IV, as for these categories there is reliable data, verified on the ground, and they are managed in a similar way, thus enabling us to assume that they all have the same biodiversity conservation values. The area data for the WDPAs were added to the corresponding ecoregions and we then calculated the area occupied by WDPAs as a percentage of the total area of each ecoregion.

Integrating the factors into the Conservation Status Index. The weights for the different factors (i.e. unique habitats, intact forest landscapes, degree of fragmentation and degree of protection) and the method for integrating them into the Conservation index were as proposed by Burgess et al., (2006) and by Ricketts et al., (1999). These variables were multiplied by their weight (Table 3) and then added together to obtain the Conservation Status Index. In this way, the scores that can be obtained by an ecoregion vary between a minimum of 0 and a maximum of 100 (Table 3). The variables awarded the most weight are those that indicate the quality of an ecosystem in terms of its size and homogeneity. Then, the values were scaled according to this criterion and qualitative ranges were generated using quartiles (Table 4).

Table 3: Values assigned on the basis of conservation status obtained from the G200 cartography

\begin{tabular}{lr}
\hline \multicolumn{1}{c}{ Factors } & $\begin{array}{r}\text { Maximum } \\
\text { Score }\end{array}$ \\
\hline Unique Habitats & 40 \\
Preservation & 25 \\
Intact Forest Landscapes & 20 \\
Degree of Fragmentation & 15 \\
Degree of Protection & \\
\hline
\end{tabular}

Table 4: Criteria for assigning ecoregions within biomes to the different categories

\begin{tabular}{ll}
\hline Categories & $\begin{array}{c}\text { Conservation } \\
\text { Status }\end{array}$ \\
\hline Very High & First quartile \\
High & Second quartile \\
Moderate & Third quartile \\
Low & Fourth quartile \\
\hline
\end{tabular}

\subsubsection{Integrating the Ecological Index}

The Distinction and Conservation Status Indices were constructed using a qualitative cross-tabulation that prioritized the most valuable elements, given that high biodiversity and quality values also imply high ecological values in the environment (Ricketts et al., 1999) (Table 5). 
Table 5: Criteria for assigning ecoregions within biomes to the different categories in the Ecological Index.

\section{Conservation Status Index}

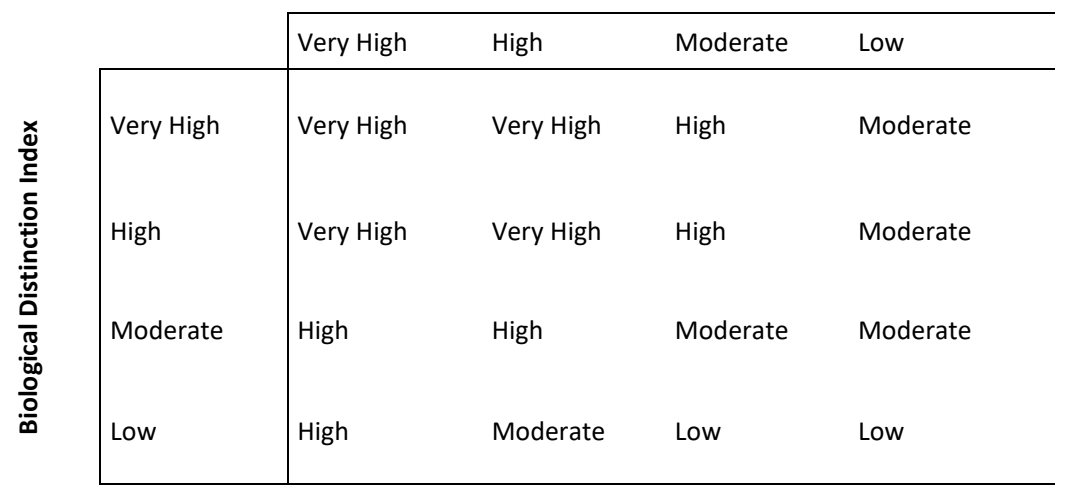

\subsection{Post-Fire Vegetation Regeneration Delay}

The delay in the regeneration of vegetation after a fire is an indicator of the difficulties faced by the environment when recovering naturally from fire. It depends on the various strategies adopted by forest species that have adapted to fire and also on the physical state of the soil after the fire. This study provides a dynamic approach which includes an assessment of the alteration of the fire regime. Habitats that have not adapted to the change in fire regimes observed in recent decades will also be assessed.

\subsubsection{Adaptation of the Vegetation to Fire Regimes}

We used the two cartographies provided by Shlisky et al., (2007), which were generated in collaboration with WWF, the Nature Conservancy (TNC), the University of Berkeley and the IUCN. Firstly, the ecoregions were grouped into fire regimes characterized by fire behaviour, plant strategies in response to fire, climatic variables and human use of fire as a forest management tool. Secondly, the ecoregions were grouped together on the basis of the alteration of the natural state of fire regimes, measured in terms of frequency, severity, size and seasonality. The first grouping includes fire-dependent, sensitive and independent fire regimes, while the second classifies ecoregions according to intact, altered and highly altered fire regimes.

After reviewing the data base, 660 terrestrial ecoregions were maintained (repeated and confusing information was eliminated, as were ecoregions without data, covered with ice or rock). To estimate the adaptation of the ecoregions to fire regimes, the two factors (regimes and their alteration) were integrated through a qualitative cross-tabulation (Table 6).

The lowest values for Adaptation to Fire Regimes were for the independent and sensitive categories, while the highest were for the ecoregions that were well adapted to fire. In ecosystems that are well adapted to fire, it plays a fundamental role in the conservation of biodiversity. However, in poorly adapted ecosystems, fire can cause serious problems in the recovery and conservation of biodiversity because the plants do not have the necessary strategies to cope with and recover from it (Shlisky et al., 2007). 
Table 6: Criteria for assigning ecoregions to the different categories of adaptation to fire regimes

Natural Condition Fire

299

\begin{tabular}{|c|c|c|c|}
\hline & \multicolumn{3}{|c|}{ Natural Condition Fire } \\
\hline & Very Degraded & Degraded & Intact \\
\hline Independent & Low & Low & Moderate \\
\hline Sensitive & Low & Moderate & High \\
\hline Dependent & Moderate & High & Very High \\
\hline
\end{tabular}

\subsubsection{Soil Erosion Potential}

Post-fire soil erosion can reduce the recovery capacity of the vegetation, and consequently of the ecosystem. The expansion capacity of the roots depends on the quality of the soil, in terms for example of its texture. This is why, after a fire, regeneration of the vegetation does not begin instantaneously. The soil must first recover its original structure and composition and this takes time. The Global Soil Erosion map (Borrelli et al., 2017) was developed using the Revised Universal Soil Loss Equation (RUSLE) with a spatial resolution of $250 \mathrm{~m}$.

Potential soil losses were calculated in tons per pixel. The potential soil erosion per ecoregion (tn / ha) was estimated by adding together all the soil losses and then dividing by the total area. The values were then transformed into a categorical variable according to the criterion for soil erosion due to water, proposed by the Food and Agriculture Organization of the United Nations (FAO) (FAO/UNEP/UNESCO, 1979) (Table 7), which is also applicable to fire erosion processes (Chuvieco et al., 2014).

Table 7: FAO criteria for assigning ecoregions to different categories of potential soil erosion.

\begin{tabular}{lr}
\hline Categories & \multicolumn{1}{c}{ Values (tn/ha year) } \\
\hline Low & $0-20$ \\
Moderate & $20-50$ \\
High & $50-200$ \\
Very High & $>200$ \\
\hline \hline
\end{tabular}

\subsubsection{Combining the factors to estimate Post-Fire Vegetation Regeneration Delay}

The two factors - Adaptation of Vegetation to Fire and Potential Soil Erosion - were combined by qualitative crosstabulation (prioritizing the most valuable element) to obtain the Post-Fire Regeneration Delay index (Table 8). This is an indicator of the time required for an ecosystem to regenerate naturally, i.e. for it to recover a structure and composition similar to that that existed pre-fire. Therefore, the higher the delay values, the greater the vulnerability to fire. This factor is the opposite of the post-fire regeneration capacity index calculated by other 
authors in local studies (Baeza et al., 2007). Post-Fire Regeneration Delay values from High to Very High were assigned to ecoregions with a Moderate or Low Adaptation to Fire and High Potential Soil Erosion values. The lowest Regeneration Delay values corresponded to ecoregions that were well adapted to fire and had low soil erosion potential.

Table 8: Criteria for assigning ecoregions to the different Post-Fire Vegetation Regeneration Delay categories.

\begin{tabular}{|c|c|c|c|c|c|}
\hline & \multicolumn{4}{|c|}{ Potential Soil Erosion } \\
\hline & & Low & Moderate & High & Very High \\
\hline \multirow{4}{*}{ 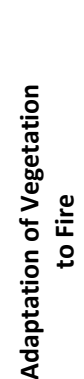 } & Very High & Low & Low & Moderate & High \\
\hline & High & Low & Low & Moderate & High \\
\hline & Moderate & Moderate & Moderate & High & Very High \\
\hline & Low & Moderate & High & Very High & Very High \\
\hline
\end{tabular}

2.7 Combining the Ecological Index and the Post-Fire Vegetation Regeneration Delay Index to form the Ecological Vulnerability Index

Once the different components of our Ecological Vulnerability to Fire Index had been obtained, they were combined by means of a qualitative cross-tabulation in which the most valuable component was prioritized (Table 9). In other words, the potential ecological losses due to fires were estimated. The lower the Post-Fire Regeneration Delay values, the lower the impacts of fire.

Table 9: Criteria for assigning ecoregions to the different Ecological Vulnerability Index categories.

\begin{tabular}{|c|c|c|c|c|}
\hline \multicolumn{5}{|c|}{ Post-Fire Vegetation Regeneration Delay } \\
\hline & Low & Moderate & High & Very High \\
\hline Low & Low & Low & Moderate & High \\
\hline Moderate & Low & Moderate & Moderate & High \\
\hline High & Moderate & High & Very High & Very High \\
\hline Very High & High & High & Very High & Very High \\
\hline
\end{tabular}




\section{Results}

\subsection{Ecological Value by ecoregion}

Figure 1 shows the Ecological Value by ecoregion in terms of Biological Distinction (Fig. A2) and Conservation Status (Fig. A3). Ecoregions of increasing ecological value are shown in a range of tones from light green to dark green.

\section{Ecological Value}

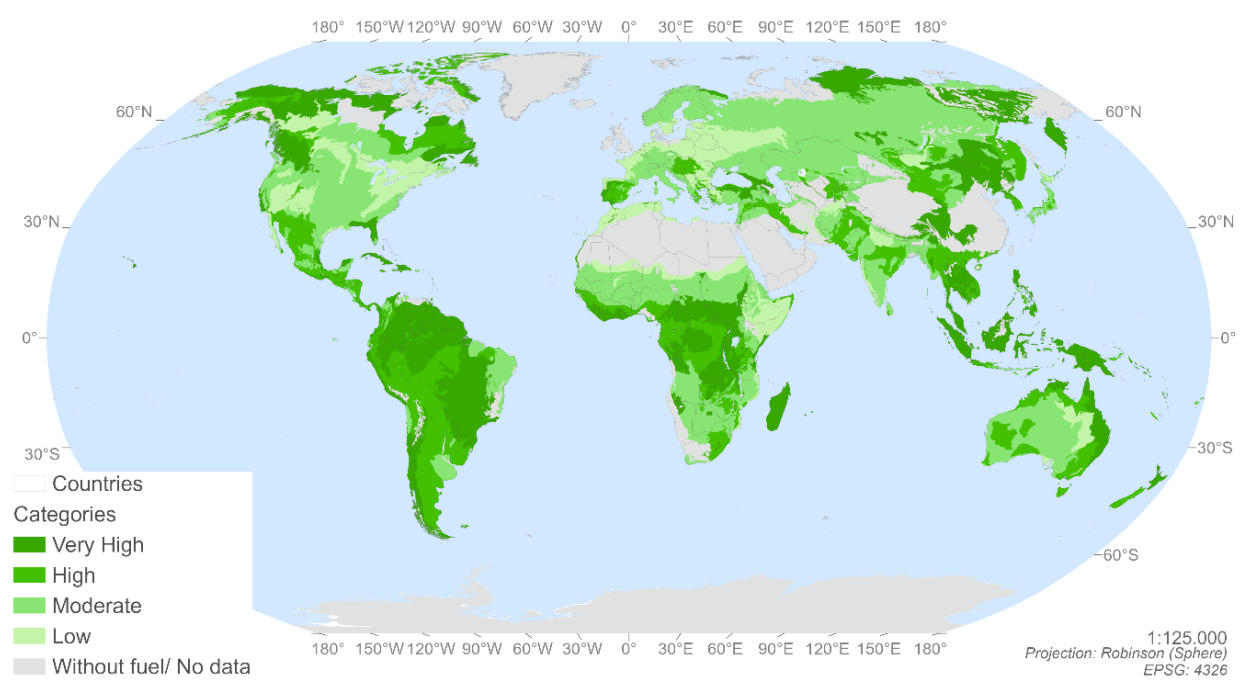

Figure 1: Spatial distribution of Ecosystem Ecological Value by ecoregion calculated by combining the Biological Distinction Index (by ecoregion evaluated within the biome to which it belongs) and the Conservation Status Index (by ecoregion).

There are 220 ecoregions with Very High Ecological values, 163 with High values, 206 with Moderate values and 59 with Low values. The ecoregions with the highest Ecological Values (Fig. 1) are located in temperate zones, such as British Columbia, Florida, forests in the US and European Mediterranean, China, Thailand, New Zealand; and in the tropical and subtropical regions, for example the Yucatan Peninsula, the Amazon Basin, Sierra Leone, Cameroon, the Congo Basin, Zambia, Madagascar, New Guinea and northern Australia. Boreal areas, such as Canada and Russia, also show high ecological values.

\subsection{Post-Fire Regeneration Delay by Ecoregion}

Figure 2 shows the Post-Fire Regeneration Delay, in terms of Adaptation of Vegetation to Fire (produced by combining the plant strategies and fire-regime alteration factors) (Fig. A4) and Potential Soil Erosion (Fig. A5). The very high and high Delay values, highlighted in dark purple tones, are for areas with high Erosion and low Adaptation to Fire, while the moderate and low values, highlighted in lighter lilac tones, are associated with vegetation with very high and high Adaptation to Fire values and moderate or low Erosion values. 


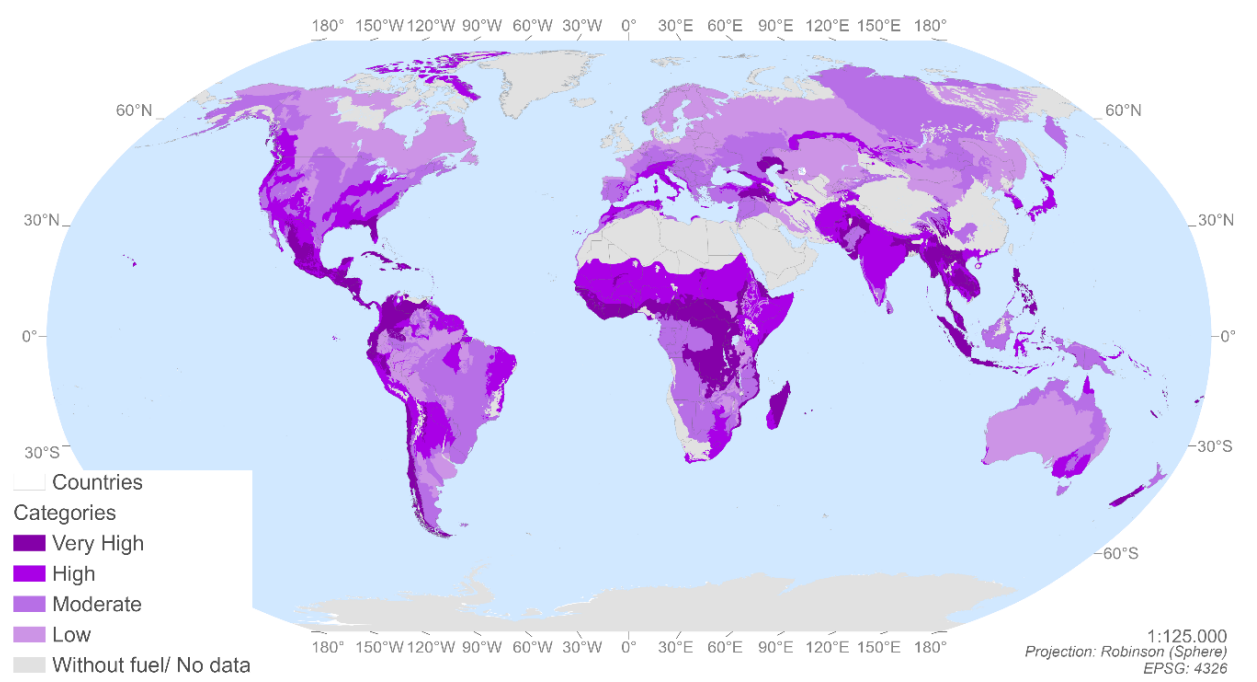

Figure 2: Spatial distribution of Post-fire Regeneration Delay Values by ecoregion calculated by combining the Adaptation to Fire and the Potential Soil Erosion values by ecoregion.

Of the 647 ecoregions evaluated, 154 had very high Post-fire Regeneration Delay values, 271 had high values, 157 had moderate values and 120 had low values. The least resilient zones (with low or moderate Adaptation to Fire and high or very high Potential Soil Erosion) belonged to temperate regions such as Florida, the Yucatan Peninsula, eastern United States, the forests of California, Chile and the Spanish Mediterranean and forests in the Caucasus, Himalayas and New Zealand; and in tropical and subtropical areas, for example in Colombia, Ecuador, the Congo Basin, Zambia, Tanzania, Madagascar, countries bordering the Tibet Autonomous Region, the Philippines, Bangladesh, India and New Zealand.

By contrast, the most resilient areas of the planet (very high or high Adaptation to Fire values and low or moderate Potential Soil Erosion) are in the temperate broadleaf and mixed forests of northern Europe, the boreal forests of Canada and Russia, Mediterranean forests, the woodlands and scrubs of southern Australia, and the temperate grasslands, savannas and shrublands of Euro-Asia.

\subsection{Ecological Vulnerability to Fire by ecoregion}

\subsubsection{Spatial distribution}

Figure 3 shows the Ecological Vulnerability to Fires by ecoregion. These values were calculated by combining the delay in post-fire regeneration and the potential ecological damages. In other words, this map shows the intensity of potential damage and the capacity to regenerate after wildfires. The areas with the highest values are shown in dark red and correspond to those with significant Post-Fire Regeneration Delay values and high Ecological Index values. By contrast, the areas shown in lighter salmon tones correspond to ecoregions that are not particularly vulnerable to fire and would incur few potential ecological losses, since they have low Ecological Index and low Regeneration Delay values. 


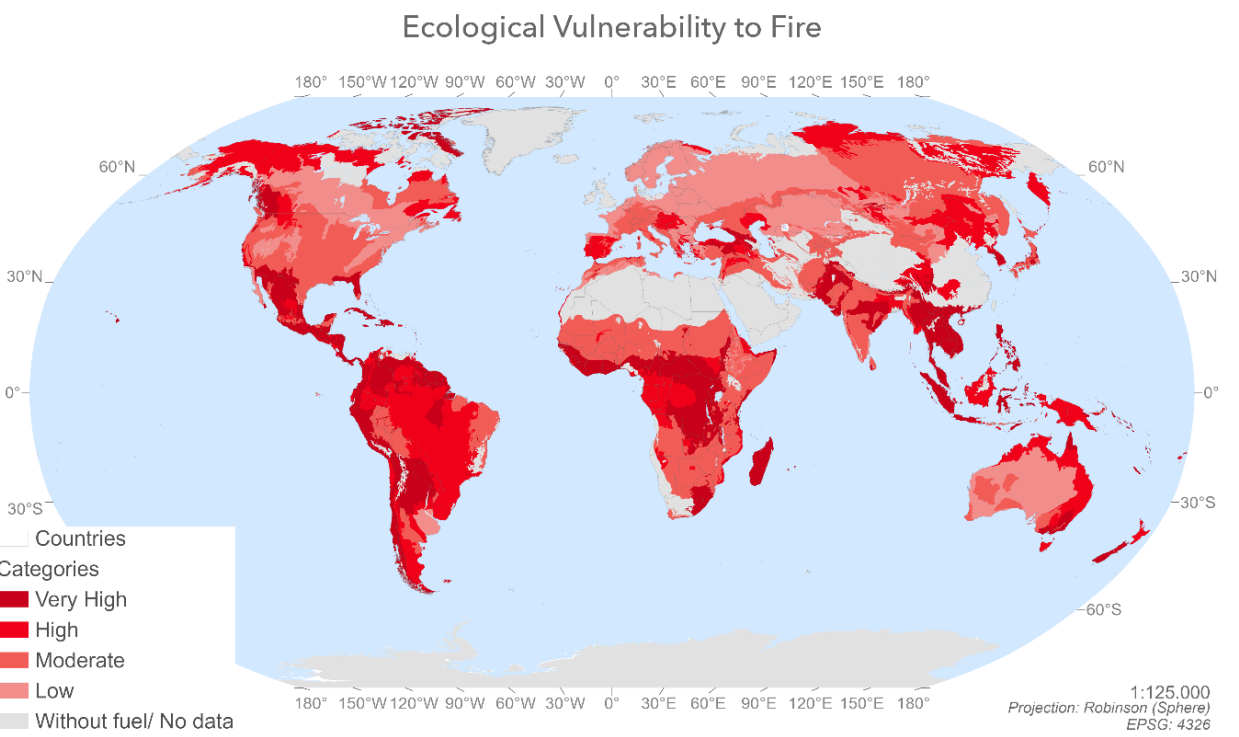

Figure 3: Spatial distribution of Ecological Vulnerability to Fire calculated by combining the Post-Fire Regeneration Delay values and the Ecosystem Ecological Values by ecoregion.

Of the 647 ecoregions analysed, 246 had very high Vulnerability to Fire values, 155 had high values, 182 were moderately vulnerable and 77 had low values. The areas that would suffer the greatest ecological losses per biome in the event of fire are the temperate zones of British Columbia, the Himalayas, central China, California, Spain, South Africa, Florida, South Sudan, New Zealand, Mongolia, eastern Australia, Chile, Hungary, Romania, Croatia, Serbia, Italy and the Caucasus area; and tropical and subtropical areas such as Mexico, Central America, the Amazon Basin, Sierra Leone, Cameroon, Guinea, the Congo Basin, Paraguay, Argentina, Uruguay, Madagascar, Borneo, Sumatra, the Philippines, Namibia and northern Australia. The ecosystems of the Canadian and Russian boreal forests and the Bolivian and Chinese montane grasslands and shrublands are also vulnerable to fire.

\subsubsection{Biome area assessment}

Almost $50 \%$ of the ecoregions have either very high or high Ecological Vulnerability to Fire values (calculated by combining the Post-Fire Regeneration Delay and the Ecological indices), while only $21 \%$ of ecoregions have low Ecological Vulnerability to Fire. This is due to an increase in the frequency and intensity of large forest fires.

The terrestrial biomes that contain most land in the very high and high Vulnerability categories as a proportion of their total area are: tropical and subtropical moist broadleaf forests, tundra, mangroves, tropical and subtropical coniferous forests, and tropical and subtropical dry broadleaf forests.

Within the very high Vulnerability to Fires category, the dominant terrestrial biomes are: tropical and subtropical moist forests, tropical and subtropical grasslands, savannas and shrublands, and xeric shrublands. By contrast, the least common biomes in this category are: wetlands, temperate grasslands, savannas and shrublands, and mangroves. Boreal forests do not have any areas with very high vulnerability values.

Of the $106,605,491 \mathrm{~km}^{2}$ considered in this study (Table 10), the area classified as having very high vulnerability to fires consisted (from highest to lowest) of $7,611,385 \mathrm{~km}^{2}$ of tropical and subtropical moist broadleaf forests, 
$5,905,304 \mathrm{~km}^{2}$ of tropical and subtropical grasslands, savannas and shrublands, 1,980,099 $\mathrm{km}^{2}$ of xeric shrublands, $1,593,959 \mathrm{~km}^{2}$ of tropical and subtropical dry broadleaf forests, $1,300,302 \mathrm{~km}^{2}$ of temperate broadleaf and mixed forests, $1,170,778 \mathrm{~km}^{2}$ of temperate conifer forests, $1,053,305 \mathrm{~km}^{2}$ of montane forests and shrublands, 556,032 $\mathrm{km}^{2}$ of tundra, $524,545 \mathrm{~km}^{2}$ of tropical and subtropical conifer forest, 172,422 $\mathrm{km}^{2}$ of Mediterranean forests, woodlands and scrubs, $154,022 \mathrm{~km}^{2}$ of mangroves, $87,651 \mathrm{~km}^{2}$ of temperate grasslands, savannas and scrublands; and finally $25,131 \mathrm{~km}^{2}$ of flooded grasslands and savannas.

By contrast, if we look at the different biomes (Table 10), the most vulnerable (from highest to lowest) are as follows: Tropical and subtropical moist coniferous forests with $75.07 \%$ of their area classified as very high vulnerability, mangroves with $59.61 \%$, tropical and subtropical dry broadleaf forests with $53.08 \%$, tropical and subtropical moist broadleaf forests with $41.82 \%$, montane grasslands and shrublands with $33.83 \%$, temperate conifer forests with $29.65 \%$, tropical and subtropical grasslands, savannas and shrublands with $29.27 \%$; xeric shrublands with $14.02 \%$, tundra with $13.55 \%$, temperate broadleaf and mixed forests with $12.22 \%$, Mediterranean forests, woodlands and scrubs with $5.38 \%$, flooded grasslands and savannas with $2.93 \%$ and, lastly, temperate grasslands, savannas and shrubs with $0.88 \%$. None of the 'Boreal forests and taigas' biome falls within the very high vulnerability category, but around $20 \%$ of its area is classified as high vulnerability.

As regards the biomes with the lowest Vulnerability to Fire values as a proportion of their total area (Table 10), the temperate broadleaf and mixed forests stand out (44.85\%) followed by boreal forests and taiga (41.37\%), xeric shrublands (35.01\%), and Mediterranean forests, woodlands and scrubs (31.85\%). The mangroves biome is also worth highlighting in that its entire area is vulnerable to fire (Table 10). 
https://doi.org/10.5194/nhess-2021-285

Preprint. Discussion started: 13 October 2021

(c) Author(s) 2021. CC BY 4.0 License.

Table 10: Number of ecoregions, surface area and percentage of land ecologically vulnerable to fires.

\begin{tabular}{|c|c|c|c|c|c|}
\hline Biome & $\begin{array}{c}\text { Percentage of total } \\
\text { area studied by biome }\end{array}$ & $\begin{array}{l}\text { Vulnerability } \\
\text { Categories }\end{array}$ & Ecoregions & $\mathbf{k m}^{2}$ & $\begin{array}{l}\text { Percentage } \\
\text { per biome }\end{array}$ \\
\hline \multirow{4}{*}{$\begin{array}{l}\text { Tropical \& Subtropical Moist } \\
\text { Broadleaf Forests }\end{array}$} & \multirow{4}{*}{92.05} & Very High & 105 & 7611385 & 41.82 \\
\hline & & High & 55 & 8318171 & 45.70 \\
\hline & & Moderate & 20 & 1972358 & 10.84 \\
\hline & & Low & 3 & 300554 & 1.65 \\
\hline \multirow{4}{*}{$\begin{array}{l}\text { Tropical \& Subtropical Dry } \\
\text { Broadleaf Forests }\end{array}$} & \multirow{4}{*}{99.77} & Very High & 28 & 1593959 & 53.08 \\
\hline & & High & 11 & 454328 & 15.13 \\
\hline & & Moderate & 9 & 929016 & 30.94 \\
\hline & & Low & 1 & 25432 & 0.85 \\
\hline \multirow{2}{*}{$\begin{array}{l}\text { Tropical \& Subtropical Coniferous } \\
\text { Forests }\end{array}$} & \multirow{2}{*}{98.52} & Very High & 12 & 524545 & 75.07 \\
\hline & & Moderate & 2 & 174236 & 24.93 \\
\hline \multirow{4}{*}{$\begin{array}{l}\text { Temperate Broadleaf \& Mixed } \\
\text { Forests }\end{array}$} & \multirow{4}{*}{82.96} & Very High & 17 & 1300302 & 12.22 \\
\hline & & High & 14 & 1600054 & 15.03 \\
\hline & & Moderate & 19 & 2970276 & 27.91 \\
\hline & & Low & 16 & 4773459 & 44.85 \\
\hline \multirow{4}{*}{ Temperate Conifer Forests } & \multirow{4}{*}{96.62} & Very High & 19 & 1170778 & 29.65 \\
\hline & & High & 4 & 558328 & 14.14 \\
\hline & & Moderate & 20 & 1369471 & 34.69 \\
\hline & & Low & 6 & 849432 & 21.52 \\
\hline \multirow{3}{*}{ Boreal Forests \& Taiga } & \multirow{3}{*}{94.85} & High & 12 & 2753116 & 19.19 \\
\hline & & Moderate & 5 & 5659834 & 39.45 \\
\hline & & Low & 8 & 5935488 & 41.37 \\
\hline \multirow{4}{*}{$\begin{array}{l}\text { Tropical \& Subtropical Grasslands, } \\
\text { Savannas \& Shrublands }\end{array}$} & \multirow{4}{*}{100.00} & Very High & 14 & 5905304 & 29.27 \\
\hline & & High & 12 & 4217891 & 20.90 \\
\hline & & Moderate & 16 & 9362256 & 46.40 \\
\hline & & Low & 3 & 691856 & 3.43 \\
\hline \multirow{4}{*}{$\begin{array}{l}\text { Temperate Grasslands, Savannas } \\
\text { \& Shrublands }\end{array}$} & \multirow{4}{*}{98.26} & Very High & 2 & 87651 & 0.88 \\
\hline & & High & 8 & 2631992 & 26.52 \\
\hline & & Moderate & 18 & 4622103 & 46.57 \\
\hline & & Low & 8 & 2584338 & 26.04 \\
\hline \multirow{4}{*}{ Flooded Grasslands \& Savannas } & \multirow{4}{*}{78.70} & Very High & 2 & 25131 & 2.93 \\
\hline & & High & 4 & 425610 & 49.54 \\
\hline & & Moderate & 5 & 250872 & 29.20 \\
\hline & & Low & 3 & 157458 & 18.33 \\
\hline \multirow{4}{*}{$\begin{array}{l}\text { Montane Grasslands \& } \\
\text { Shrublands }\end{array}$} & & Very High & 16 & 1053305 & 33.83 \\
\hline & 6001 & High & 5 & 628994 & 20.20 \\
\hline & 60.01 & Moderate & 14 & 1089028 & 34.98 \\
\hline & & Low & 2 & 341828 & 10.98 \\
\hline & & Very High & 2 & 556032 & 13.55 \\
\hline Tundra & 3520 & High & 11 & 2916345 & 71.09 \\
\hline Iundra & 35.20 & Moderate & 3 & 385270 & 9.39 \\
\hline & & Low & 1 & 244865 & 5.97 \\
\hline & & Very High & 3 & 172422 & 5.38 \\
\hline Mediterranean Forests, & 99.47 & High & 5 & 624670 & 19.50 \\
\hline Woodlands \& Scrubs & 99.41 & Moderate & 21 & 1385415 & 43.25 \\
\hline & & Low & 9 & 1020796 & 31.87 \\
\hline & & Very High & 13 & 1980099 & 14.02 \\
\hline Xeric Shrublands & 5064 & High & 8 & 882566 & 6.25 \\
\hline & & Moderate & 23 & 6314163 & 44.71 \\
\hline & & Low & 14 & 4944312 & 35.01 \\
\hline & & Very High & 9 & 154022 & 59.61 \\
\hline Mangroves & 74.59 & High & 3 & 55773 & 21.58 \\
\hline & & Moderate & 4 & 48602 & 18.81 \\
\hline Total & 78.85 & & & 106605491 & \\
\hline
\end{tabular}




\section{Discussion}

This study presents an index for assessing and mapping Ecological Vulnerability to Fire on a global scale on the basis of Ecological Index and Post-Fire Regeneration Delay values. Our results show that global ecological value may be reduced by as much as $50 \%$ due to the perturbation by fire of ecosystems that are poorly adapted to fire and have degraded fire regimes. The terrestrial biomes most affected are the tropical and subtropical moist broadleaf forest, tundra, mangroves, tropical and subtropical coniferous forests, and tropical and subtropical dry broadleaf forests. The most important determining factor is fire regime, in that current alterations to the fire regime are causing areas that were previously considered to be relatively safe to now be classified as vulnerable to fire. This study attempts to evaluate Ecological Vulnerability to Fire on a global scale. Although the databases used were carefully examined before selection, the results are inevitably affected by the different spatial units, the lack of information, the lack of updating and the uncertainty in the data for some ecoregions; and to a lesser extent, by the way we combined the factors in the different indices.

In order to avoid problems with estimations of Species Richness, we used field data which measured this variable exactly. In comparison with the use of remote sensing data, the study by Duro et al., 2007 shows that the Net Primary Productivity (NPP) value overestimates biodiversity in areas covered by replantations. This is because forests made up of young trees or saplings, which fix more carbon than mature forests, are being overestimated. In addition, the NPP biodiversity values are evaluated in terms of the number of different individuals and not in terms of the number of different species, a fundamental indicator for establishing the biodiversity values of particular environments (Nagendra \& Rocchini, 2008).

As regards the ecosystem functionality variables, remote sensing data has the advantage of providing updated information for the entire planet. Despite the extensive bibliographic review carried out as part of this research, we were unable to find a concise way of combining these variables due to the fact that little research has been done on the specific issue of ecosystem functionality. This is one of the first studies of ecological vulnerability to fire that takes this issue into account, by integrating it into ecological value. This is of the utmost importance since fire affects both the functioning of the ecosystem and its ability to maintain itself (Pausas \& Ribeiro, 2017).

Our Ecological Vulnerability to Fire Index highlights those biomes considered most susceptible (tropical and subtropical moist broadleaf forests, tundra, mangroves, tropical and subtropical coniferous forests, and tropical and subtropical dry broadleaf forests) to suffering a decline in their ecological value. Two clusters can be observed. The first consisted of mangroves and tropical and subtropical forests associated with tropical latitudes. These regions obtained high or very high Ecological Vulnerability to Fire values due to the fact that they had the highest ecological values and also had high regeneration delay values. Within the ecological value dimension of this index, tropical latitudes show the highest values for both biological distinction and conservation status due to the fact that they host the highest ratios for biodiversity and endemisms, and have high ecosystem functionality values and low levels of landscape degradation. They also have high levels of official protection. In addition, these areas have the highest regeneration delay values due to the low adaptation capacity of the vegetation, the high current alterations of the natural fire regime and the high potential soil erosion after fire disturbance. For this reason, if a wildfire occurs in biomes such as mangroves, tropical and subtropical moist and broadleaf forests, and coniferous forests, the ecological value of these biomes will almost certainly be heavily degraded due to the fact that most areas within these biomes fall within the very high Ecological Vulnerability to Fire category of our index. 
Second on this list of the biomes with the largest area with a high potential for degradation by fire is tundra, due to the fact that it scores highly in both Ecological Value and Regeneration Delay, the two components of our Vulnerability to Fire index. In terms of the first component, the intrinsic behaviour of the tundra biome explains why it has similar ecological values to the biomes in the first cluster. However, the high levels of Regeneration Delay have a different explanation. Within the Regeneration Delay sub-index, tundra has a fire regime in which the vegetation is well adapted to fire due to the fact that, unlike the tropical and subtropical biomes, frequent fire disturbance has been a constant feature of its development. In spite of this, tundra biomes have large areas in the high or very high Vulnerability to Fire categories due to the fact that they score high values for potential soil erosion and fire regime modification. As a result, pre-fire ecological values will be difficult to recover if the wildfire occurs under a different regime than that to which the vegetation has adapted. This is why large swathes of the tundra biome are classified within the very high Vulnerability to Fire category of our index.

In the end, both clusters meet the two requirements of our index for them to be considered highly vulnerable to losing their pre-fire ecological values in the event of perturbation by fire: (i) high Ecological Index values and (ii) high Regeneration Delay values. Within the Ecological Index, the factors which led the different ecoregions to obtain high Ecological Index values are related to the ability of their ecosystems to host different kinds of plants and wildlife (endemisms, functional and structural biodiversity) and the degree of official protection afforded to them. For its part, the factor with the greatest impact on Regeneration Delay values is the alteration of the fire regime, as this means that the strategies developed by the vegetation in response to fire are no longer fit for purpose, and cannot help it recover the Ecological Index values existing prior to the fire. This is why alteration of the fire regime is the most important factor and the most closely associated with human action in that it is largely a consequence of human-induced global change. In this context, a determined shift towards more sustainable lifestyles would reduce ecological vulnerability to fire.

In this sense, up to $50 \%$ of the terrestrial ecosystem analysed in this study is vulnerable to potential degradation of its ecological value due to the changes taking place in fire regimes. This estimate coincides with the climate change projections that indicate an increase in the frequency and intensity of large forest fires, recently dubbed "megafires", as a result of longer, drier fire seasons (Stephens et al., 2013, Aponte et al., 2016). This increase, at least in the medium term, will lead to new fire regimes and an increase in aridity in some regions as a consequence of climate change (Flannigan et al., 2009). Terrestrial ecosystems will need to adapt not only to changes in mean climatic variables, but also to greater variability with increased risk of extreme weather events, such as prolonged droughts, storms, and floods (Lindner et al., 2010). As a result of this process of change, forest fires have become one of the main environmental problems at a global scale today.

If we compare our evaluation of ecological vulnerability to fire with the study carried out by Chuvieco et al., (2014), substantial differences can be observed. Firstly, in our study the temperate conifer forests in the British Columbia region had high vulnerability values compared to those estimated with their index. Lightning fires are frequent in this area and the ecosystem has learnt to adapt to them. However, in our study, we included the possibility of change in the fire regime, which indicates that these areas are in fact quite vulnerable to fire. Nitschke $\&$ Innes (2013) found that due to climate change, fire regimes in boreal areas are changing in frequency and area. If we look for example at the temperate broadleaf and mixed forests of Patagonia and the boreal forests of Alaska, although both have adapted to fire to some extent, they also obtained high vulnerability to fire values, because of 
the alteration in their fire regimes due to climate change, as indicated by Higuera et al., (2009) and Landesmann et al., (2015).

If we turn our attention to the tropical and subtropical dry broadleaf forests of India, one of the greatest biodiversity areas in the world, in the study by Chuvieco et al., (2014) they were considered to have low vulnerability to fire because their plant communities had adapted to it. However, our study offers a different assessment, awarding these parts of India higher Ecological Vulnerability to Fire values. This may be due to the fact that our model takes into account a variable that characterizes the delay in post-fire regeneration as a result of changes in the fire regime. In this sense, Kodandapani, Cochrane, \& Sukumar (2008) refer to the fact that logging and forest fragmentation, grazing and the collection of non-timber forest products are affecting the behaviour of fire in these forests.

In relation to the Amazon Basin, in this study the highest vulnerability to fire values only occur in the regions close to the mouth. This may be due to the way in which the Species Richness variable is characterized. Species Richness, adjusted in line with the size of the ecoregion, enables us to compare ecoregions of different sizes so as to assess the ecological value fairly, rather than just comparing the raw data (Ricketts et al., 1999). It should be noted that the areas near the coast, which have a more open plant canopy that allows sunlight to penetrate, have managed to develop undergrowth vegetation that supports other forms of life (greater species richness understood as diversity of species rather than abundance of species). In this case, it is important to realize that we are dealing with tropical and subtropical moist broadleaf forests, which have not developed in the presence of fire. The introduction of fire into these ecosystems could therefore result in significant losses in that plant species have never developed post-fire regeneration strategies. This is why the small ecoregions at the mouth of the Amazon suffer slightly greater losses due to fire, compared with the large central ecoregions (Cochrane \& Laurance, 2002). In addition, in the present study, the large temperate broadleaf and boreal forests of northern Europe and Russia show less ecological vulnerability to fires than estimated by Chuvieco et al. (2014). This may be due to the fact that our model, by following a representative criterion of estimating the ecological value within the biome, gives higher species ratios to smaller regions, and less weight to the large ecoregions in northern Europe and Russia. This is why, in our study, on a global scale, these ecoregions obtained a low vulnerability to fire value given that to destroy all their ecological wealth, their entire immense area would have to be affected.

At various points in our study, we combined different factors to create an index. Although the model is based on the bibliography, improvements such as multi-criteria evaluations involving expert participation could be applied in the future in a bid to enrich the proposed approach (Gómez-Delgado \& Tarantola, 2006). We could also apply machine-learning techniques to enable us to establish a more precise relationship between the different factors (Semeraro et al., 2016). For all of the above, the resulting estimates should be interpreted as an initial approximation.

Despite the aforementioned limitations, this study presents a robust, pragmatic and intuitive aggregation methodology. The negative effects of fires can only be identified after the fire. This means that a model of ecological vulnerability to fire cannot be correctly validated on a global scale as there is no representative sample for doing so. However, at regional and local scales, there are studies that monitor post-fire ecological damage (Gouveia et al., 2010). This is because the effects of fire can best be understood at these scales. As this methodology can be replicated easily and the factors can be adapted to the model (to a greater or lesser extent depending on the information available), the model could and indeed should be validated at these scales. 
The ecological vulnerability model at a global scale is also very useful as it can help us to understand the global impacts that fires could have on ecosystems and on climate change. In addition, on a global scale, there are studies that focus on the early detection of places where fires may occur (based on climate data) (De Groot et al., 2006). If these studies were combined with our map, they could help prevent or mitigate ecological losses, as well as encourage the development of action plans in the event of fire, aimed at accelerating the regeneration of the ecosystem.

This model could also be used in the field of forest management to prioritize fire intervention areas in terms of ecological value, as proposed by Burgess et al. (2006) and Ricketts et al. (1999). If this vulnerability index were included in fire management plans, in the event of several fires breaking out at the same time, priority action could be directed at the most vulnerable area in order to protect its ecological value. Although in these cases, the protection of human lives is normally the first priority, future studies are expected to develop and integrate the idea of socioeconomic vulnerability into this ecological component of vulnerability. It would therefore seem more logical to develop policies, prevention and restoration plans in the most vulnerable areas in order to preserve them. Although this model for evaluating ecological vulnerability to fires on a global scale is an initial approximation, it allows us to identify which ecoregions of the different biomes are more likely to have their ecological value impaired by fire and why. In future research, we intend to carry out a sensitivity analysis of the variables in order to assess their individual impact on ecological vulnerability to fire.

\section{Conclusions}

This paper makes an initial assessment of the spatial distribution of ecological vulnerability to fire on a global scale. The methodology we implemented enabled us to systematically integrate all the ecological components likely to be affected by forest fires. A novel aspect of this methodology is the way it integrates the variables in the biological distinction index, the characterization of functional diversity and the fact that it takes into account the impact of the alteration of the fire regime in post-fire regeneration delay. This index made it possible to identify the most susceptible biomes in terms of the loss of their ecological values, and it could be useful as a starting point for developing plans and strategies in response to global change scenarios.

At a global level, our results show that almost $50 \%$ of the world's land surface is vulnerable to a decline in its ecological value due to fire as a result of the current alteration of the fire regime. The terrestrial biomes with the highest degree of ecological vulnerability to fire were found in the tropical and subtropical moist broadleaf forests; tundra; mangroves; tropical and subtropical coniferous forests; and tropical and subtropical dry broadleaf forests. The greatest determining factor is the fire regime, a problem that is being exacerbated by current alterations, in that areas that were previously considered to be relatively safe now have much higher vulnerability values due to alterations in their fire regime, caused by global climate change.

Author contributions

Fátima Arrogante-Funes: Conceptualization, data curation, formal analysis, investigation, methodology, resources, software, validation, visualization, writing - original draft preparation.

Inmaculada Aguado: Conceptualization, funding acquisition, investigation, methodology, project administration, supervision, writing - review \& editing. 
Emilio Chuvieco: Conceptualization, funding acquisition, investigation, methodology, project administrator, resources, supervision, writing - review \& editing.

\section{Acknowledgements}

This research was funded by the MCIU/AEI/FEDER, UE), RTI2018-097538-B-I00- Global analysis of human factors of fire risk (AnthropoFire Project). In addition, Fátima Arrogante-Funes was supported by a predoctoral scholarship (FPI) from the Spanish Ministry of Science, Innovation and Universities (PRE2019-089208). We would also like to thank ESA, Kier, the World Wildlife Fund, Moreno-Martínez, Olson, Burgess, Potapov, Hoekstra, IUCN \& UNEP-WCM, Borrelli and Shlisky for the databases.

\section{References}

Abson, D. J., Dougill, A. J., \& Stringer, L. C. (2012). Using Principal Component Analysis for information-rich socio-ecological vulnerability mapping in Southern Africa. Applied Geography, 35(1-2), 515-524. https://doi.org/10.1016/j.apgeog.2012.08.004

Alcasena, F. J., Salis, M., Nauslar, N. J., Aguinaga, A. E., \& Vega-García, C. (2016). Quantifying economic losses from wildfires in black pine afforestations of northern Spain. Forest Policy and Economics, 73, 153-167. https://doi.org/10.1016/j.forpol.2016.09.005

Aretano, R., Semeraro, T., Petrosillo, I., De Marco, A., Pasimeni, M. R., \& Zurlini, G. (2015). Mapping ecological vulnerability to fire for effective conservation management of natural protected areas. Ecological Modelling, 295, 163-175. https://doi.org/10.1016/j.ecolmodel.2014.09.017

Baeza, A. M. J., Valdecantos, A., Alloza, J. A., Vallejo, V. R., Centro, I., Ambientales, D. E., Darwin, C. C. R., \& Tecnoldgico, P. (2007). Human Disturbance and Environmental Factors as Drivers of Long-Term Post-Fire Regeneration Patterns in Mediterranean Forests Stable URL: http://www.jstor.org/stable/4499220 REFERENCES Linked references are available on JSTOR for this article : long-term . 18(2), 243-252.

Bajocco, S., Salvati, L., \& Ricotta, C. (2011). Land degradation versus fire: A spiral process? Progress in Physical Geography, 35(1), 3-18. https://doi.org/10.1177/0309133310380768

Barrio, M., Loureiro, M., \& Chas, M. L. (2011). Aproximación a las pérdidas económicas ocasionadas a corto plazo por los incendios forestales en Galicia en 2006. Economía Agraria y Recursos Naturales, 7(14), 45. https://doi.org/10.7201/earn.2007.14.03

Berry, P. M., Rounsevell, M. D. A., Harrison, P. A., \& Audsley, E. (2006). Assessing the vulnerability of agricultural land use and species to climate change and the role of policy in facilitating adaptation. Environmental Science and Policy, 9(2), 189-204. https://doi.org/10.1016/j.envsci.2005.11.004

Bond, W. J., Woodward, F. I., \& Midgley, G. F. (2005). The global distribution of ecosystems in a world without fire. New Phytologist, 165(2), 525-538. https://doi.org/10.1111/j.1469-8137.2004.01252.x

Borrelli, P., Robinson, D. A., Fleischer, L. R., Lugato, E., Ballabio, C., Alewell, C., Meusburger, K., Modugno, S., Schütt, B., Ferro, V., Bagarello, V., Oost, K. Van, Montanarella, L., \& Panagos, P. (2017). An assessment of the global impact of 21 st century land use change on soil erosion. Nature Communications, 8(1). https://doi.org/10.1038/s41467-017-02142-7

Bowman, D. M. J. S., Balch, J. K., Artaxo, P., Bond, W. J., Carlson, J. M., Cochrane, M. A., D’Antonio, C. M., DeFries, R. S., Doyle, J. C., Harrison, S. P., Johnston, F. H., Keeley, J. E., Krawchuk, M. A., Kull, C. A., Marston, 
J. B., Moritz, M. A., Prentice, I. C., Roos, C. I., Scott, A. C., ... Pyne, S. J. (2009). Fire in the earth system. Science, 324(5926), 481-484. https://doi.org/10.1126/science.1163886

Buhk, C., Meyn, A., \& Jentsch, A. (2007). The challenge of plant regeneration after fire in the Mediterranean Basin: Scientific gaps in our knowledge on plant strategies and evolution of traits. Plant Ecology, 192(1), 1-19. https://doi.org/10.1007/s11258-006-9224-2

Burgess, N., de Lima, M. G., N., B., Blythe, S., Tompkins, I., Coad, L., \& Leverington, F. (2014). Protected Area Management Effectiveness in WWF Global Priority Places. Cambridge: UNEP-WCMC.

Burgess, N., Hales, J. D. A., Ricketts, T. H., \& Dinerstein, E. (2006). Factoring species, non-species values and threats into biodiversity prioritisation across the ecoregions of Africa and its islands. Biological Conservation, 127(4), 383-401. https://doi.org/10.1016/j.biocon.2005.08.018

Caprio, A. C., \& Graber, D. M. (2000). Returning fire to the mountains: can we successfully restore the ecological role of pre-Euroamerican fire regimes to the Sierra Nevada (D. Cole, S. McCool, \& J. O'Loughlin (eds.)). In Wilderness science in a time of change conference.

Chuvieco, E., Aguado, I., Yebra, M., Nieto, H., Martín, M. P., Vilar, L., Martínez, J., Padrón, D., Martín, S., \& Salas, J. (2007). Cartografía del peligro de incendios forestales mediante Teledetección y SIG. Teledetección Hacia Un Mejor Entendimiento de La Dinámica Global y Regional, January, 19-26.

Chuvieco, E., Aguado, I., Yebra, M., Nieto, H., Salas, J., Martín, M. P., Vilar, L., Martínez, J., Martín, S., Ibarra, P., de la Riva, J., Baeza, J., Rodríguez, F., Molina, J. R., Herrera, M. A., \& Zamora, R. (2010). Development of a framework for fire risk assessment using remote sensing and geographic information system technologies. Ecological Modelling, 221(1), 46-58. https://doi.org/10.1016/j.ecolmodel.2008.11.017

Chuvieco, E., Martínez, S., Román, M. V., Hantson, S., \& Pettinari, M. L. (2014). Integration of ecological and socio-economic factors to assess global vulnerability to wildfire. Global Ecology and Biogeography, 23(2), 245258. https://doi.org/10.1111/geb.12095

Cinner, J. E., McClanahan, T. R., Graham, N. A. J., Daw, T. M., Maina, J., Stead, S. M., Wamukota, A., Brown, K., \& Bodin, O. (2012). Vulnerability of coastal communities to key impacts of climate change on coral reef fisheries. Global Environmental Change, 22(1), 12-20. https://doi.org/10.1016/j.gloenvcha.2011.09.018 Cochrane, M. A., \& Laurance, W. F. (2002). Fire as a large-scale edge effect in Amazonian forests. Journal of Tropical Ecology, 18(3), 311-325. https://doi.org/10.1017/S0266467402002237 Collinge, S. K. (1996). Ecological consequences of habitat fragmentation: Implications for landscape architecture and planning. Landscape and Urban Planning, 36(1), 59-77. https://doi.org/10.1016/S0169-2046(96)00341-6 Cutter, S. L., Boruff, B. J., \& Shirley, W. L. (2003). Social vulnerability to environmental hazards. Social Science Quarterly, 84(2), 242-261. https://doi.org/10.1111/1540-6237.8402002

De Groot, W. J. B., Goldammer, J. G., Keenan, T., Brady, M. A., Lynham, T. J., Justice, C. O., Csiszar, I. A., \& O'Loughlin, K. (2006). Developing a global early warning system for wildland fire. V International Conference on Forest Fire Research. https://doi.org/10.1016/j.foreco.2006.08.025

Díaz-Delgado, R., Lloret, F., Pons, X., \& Terradas, J. (2002). Satellite evidence of decreasing resilience in mediterranean plant communities after recurrent wildfires. Ecology, 83(8), 2293-2303. https://doi.org/10.1890/0012-9658(2002)083[2293:SEODRI]2.0.CO;2

Dinerstein, E., Olson, D., Graham, D., Webster, A., Pimm, S., Bookbinder, M., \& Ledec, G. (1995). A Conservation Assessment of the Terrestrial Ecoregions of Latin America and the Caribbean. World Bank. 
Duguy, B., Alloza, J. A., Baeza, M. J., De La Riva, J., Echeverría, M., Ibarra, P., Llovet, J., Cabello, F. P., Rovira, P., \& Vallejo, R. V. (2012). Modelling the ecological vulnerability to forest fires in mediterranean ecosystems using geographic information technologies. Environmental Management, 50(6), 1012-1026. https://doi.org/10.1007/s00267-012-9933-3

Duguy, B., \& Vallejo, V. R. (2008). Land-use and fire history effects on post-fire vegetation dynamics in eastern Spain. Journal of Vegetation Science, 19(1), 97-108.

Duro, D. C., Coops, N. C., Wulder, M. A., \& Han, T. (2007). Development of a large area biodiversity monitoring system driven by remote sensing. Progress in Physical Geography, 31(3), 235-260. https://doi.org/10.1177/0309133307079054

ESA Land Cover CCI project team; Defourny, P. (2019): ESA Land Cover Climate Change Initiative (Land_Cover_cci): Global Land Cover Maps, Version 2.0.7. Centre for Environmental Data Analysis, date of citation. https://catalogue.ceda.ac.uk/uuid/b382ebe6679d44b8b0e68ea4ef4b701c

FAO/UNEP/UNESCO. (1979). A provisional methodology for soil degradation assessment. Food and Agricultural Organization of the United Nations, Rome.

Flannigan, M. D., Krawchuk, M. A., De Groot, W. J., Wotton, B. M., \& Gowman, L. M. (2009). Implications of changing climate for global wildland fire. International Journal of Wildland Fire, 18(5), 483-507. https://doi.org/10.1071/WF08187

Freudenberger, L., Hobson, P. R., Schluck, M., \& Ibisch, P. L. (2012). A global map of the functionality of terrestrial ecosystems. Ecological Complexity, 12, 13-22. https://doi.org/10.1016/j.ecocom.2012.08.002

Giovannini, G., \& Lucchesi, S. (1997). Modifications induced in soil physico-chemical parameters by experimental fires at different intensities. Soil Science, 162(7), 479-486.

Gómez-Delgado, M., \& Tarantola, S. (2006). GLOBAL sensitivity analysis, GIS and multi-criteria evaluation for a sustainable planning of a hazardous waste disposal site in Spain. International Journal of Geographical Information Science, 20(4), 449-466. https://doi.org/10.1080/13658810600607709

González, J. R., Kolehmainen, O., \& Pukkala, T. (2007). Using expert knowledge to model forest stand vulnerability to fire. Computers and Electronics in Agriculture, 55(2), 107-114. https://doi.org/10.1016/j.compag.2006.12.005

Gouveia, C., DaCamara, C. C., \& Trigo, R. M. (2010). Post-fire vegetation recovery in Portugal based on spot/vegetation data. Natural Hazards and Earth System Science, 10(4), 673-684. https://doi.org/10.5194/nhess$10-673-2010$

Guyette, R. P., Muzika, R. M., \& Dey, D. C. (2002). Dynamics of an Anthropogenic Fire Regime. Ecosystems, 6(4), 326-335. https://doi.org/10.1007/s10021-002-0115-7

Higuera, P. E., Brubaker, L. B., Anderson, P. M., Hu, F. S., \& Brown, T. A. (2009). Vegetation mediated the impacts of postglacial climate change on fire regimes in the south-central Brooks Range, Alaska. Ecological Monographs, 79(2), 201-219. https://doi.org/10.1890/07-2019.1

Hilton-Taylor, C. (2000). 2000 IUCN Red List of Threatened Species. IUCN, Gland, Switzerland and Cambridge, UK.

Hobson, K. A., \& Schieck, J. (1999). Changes in bird communities in boreal mixedwood forest: Harvest and wildfire effects over 30 years. Ecological Applications, 9(3), 849-863. https://doi.org/10.1890/10510761(1999)009[0849:CIBCIB]2.0.CO;2 
Hoekstra, J. M., Molnar, J. L., Jennings, M., Revenga, C., Spalding, M. D., Boucher, T. M., Robertson, J. C., Heibel, T. J., \& Ellison, K. (2010). The Atlas of global conservation: changes, challenges, and opportunities to make a difference. In Choice Reviews Online (Vol. 48, Issue 01). J. L. Molnar. Berkeley: University of California Press. https://doi.org/10.5860/choice.48-0280

Houghton, J. T., Ding, Y. D. J. G., Griggs, D. J., Noguer, M., van der Linden, P. J. Dai, X., \& Johnson, C. A. (2001). Climate change 2001: the scientific basis. The Press Syndicate of the University of Cambridge. Ippolito, A., Sala, S., Faber, J. H., \& Vighi, M. (2010). Ecological vulnerability analysis: A river basin case study. Science of the Total Environment, 408(18), 3880-3890. https://doi.org/10.1016/j.scitotenv.2009.10.002 IUCN, \& UNEP-WCMC. (2020). The World Database on Protected Areas (WDPA). Ambridge (UK): UNEP World Conservation Monitoring Centre.

Kier, G., Kreft, H., Tien, M. L., Jetz, W., Ibisch, P. L., Nowicki, C., Mutke, J., \& Barthlott, W. (2009). A global assessment of endemism and species richness across island and mainland regions. Proceedings of the National Academy of Sciences of the United States of America, 106(23), 9322-9327. https://doi.org/10.1073/pnas.0810306106

Kier, G., Mutke, J., Dinerstein, E., Ricketts, T. H., Küper, W., Kreft, H., \& Barthlott, W. (2005). Global patterns of plant diversity and floristic knowledge. Journal of Biogeography, 32(7), 1107-1116. https://doi.org/10.1111/j.1365-2699.2005.01272.x

Kirkman, L. K., Mitchell, R. J., Helton, R. C., \& Drew, M. B. (2001). Productivity and species richness across an environmental gradient in a fire-dependent ecosystem. American Journal of Botany, 88(11), 2119-2128. https://doi.org/10.2307/3558437

Kodandapani, N., Cochrane, M. A., \& Sukumar, R. (2008). A comparative analysis of spatial, temporal, and ecological characteristics of forest fires in seasonally dry tropical ecosystems in the Western Ghats, India. Forest Ecology and Management, 256(4), 607-617. https://doi.org/10.1016/j.foreco.2008.05.006

Landesmann, J. B., Gowda, J. H., Garibaldi, L. A., \& Kitzberger, T. (2015). Survival, growth and vulnerability to drought in fire refuges: implications for the persistence of a fire-sensitive conifer in northern Patagonia. Oecologia, 179(4), 1111-1122. https://doi.org/10.1007/s00442-015-3431-2

Lindner, M., Maroschek, M., Netherer, S., Kremer, A., Barbati, A., Garcia-Gonzalo, J., Seidl, R., Delzon, S., Corona, P., Kolström, M., Lexer, M. J., \& Marchetti, M. (2010). Climate change impacts, adaptive capacity, and vulnerability of European forest ecosystems. Forest Ecology and Management, 259(4), 698-709. https://doi.org/10.1016/j.foreco.2009.09.023

Mace, G. M., \& Lande, R. (1991). Assessing extinction threats: towards a reassessment of IUCN endangered species categories. Conservation Biology 5.

Midgley, G. F., \& Bond, W. J. (2015). Future of African terrestrial biodiversity and ecosystems under anthropogenic climate change. Nature Climate Change, 5(9), 823-829. https://doi.org/10.1038/nclimate2753 Moreira, F., Viedma, O., Arianoutsou, M., Curt, T., Koutsias, N., Rigolot, E., Barbati, A., Corona, P., Vaz, P., Xanthopoulos, G., Mouillot, F., \& Bilgili, E. (2011). Landscape - wildfire interactions in southern Europe: Implications for landscape management. Journal of Environmental Management, 92(10), 2389-2402. https://doi.org/10.1016/j.jenvman.2011.06.028

Moreno-Martínez, Á., Camps-Valls, G., Kattge, J., Robinson, N., Reichstein, M., van Bodegom, P., Kramer, K., Cornelissen, J. H. C., Reich, P., Bahn, M., Niinemets, Ü., Peñuelas, J., Craine, J. M., Cerabolini, B. E. L., Minden, 
V., Laughlin, D. C., Sack, L., Allred, B., Baraloto, C., ... Running, S. W. (2018). A methodology to derive global maps of leaf traits using remote sensing and climate data. Remote Sensing of Environment, 218(September), 6988. https://doi.org/10.1016/j.rse.2018.09.006 Moreno, A., \& Becken, S. (2009). A climate change vulnerability assessment methodology for coastal tourism. Journal of Sustainable Tourism, 17(4), 473-488. https://doi.org/10.1080/09669580802651681

Myers, N., Mittermeier, R. A., Mittermeier, C. G., Da Fonseca, G. A., \& Kent, J. (2010). Biodiversity hotspots for conservation priorities. Nature, 468(7326), 895. https://doi.org/10.1038/468895a Nagendra, H., \& Rocchini, D. (2008). High resolution satellite imagery for tropical biodiversity studies: The devil is in the detail. Biodiversity and Conservation, 17(14), 3431-3442. https://doi.org/10.1007/s10531-008-9479-0 Nitschke, C. R., \& Innes, J. L. (2013). Potential effect of climate change on observed fire regimes in the Cordilleran forests of South-Central Interior, British Columbia. Climatic Change, 116(3-4), 579-591. https://doi.org/10.1007/s10584-012-0522-5

Olson, D. M., \& Dinerstein, E. (2002). The Global 200: Priority Ecoregions for Global Conservation. Annals of the Missouri Botanical Garden, 89(2), 199. https://doi.org/10.2307/3298564

Olson, D. M., Dinerstein, E., Wikramanayake, E. D., Burgess, N. D., Powell, G. V. N., Underwood, E. C., D’amico, J. A., Itoua, I., Strand, H. E., Morrison, J. C., Loucks, C. J., Allnutt, T. F., Ricketts, T. H., Kura, Y., Lamoreux, J. F., Wettengel, W. W., Hedao, P., \& Kassem, K. R. (2001). Terrestrial Ecoregions of the World: A New Map of Life on Earth. BioScience, 51(11), 933. https://doi.org/10.1641/00063568(2001)051[0933:teotwa]2.0.co;2

Pausas, J. G., Carreras, J., Ferré, A., \& Font, X. (2003). Coarse-scale plant species richness in relation to environmental heterogeneity. Journal of Vegetation Science, 14(5), 661-668. https://doi.org/10.1111/j.16541103.2003.tb02198.x

Pausas, J. G., \& Ribeiro, E. (2017). Fire and plant diversity at the global scale. Global Ecology and Biogeography, 26(8), 889-897. https://doi.org/10.1111/geb.12596

Poos, M. S., Walker, S. C., \& Jackson, D. A. (2009). Functional-diversity indices can be driven by methodological choices and species richness. Ecology, 90(2), 341-347. https://doi.org/10.1890/08-1638.1

Potapov, P., Yaroshenko, A., Turubanova, S., Dubinin, M., Laestadius, L., Thies, C., Aksenov, D., Egorov, A., Yesipova, Y., Glushkov, I., Karpachevskiy, M., Kostikova, A., Manisha, A., Tsybikova, E., \& Zhuravleva, I. (2008). Mapping the world's intact forest landscapes by remote sensing. Ecology and Society, 13(2). https://doi.org/10.5751/ES-02670-130251

Preston, B. L., Yuen, E. J., \& Westaway, R. M. (2011). Putting vulnerability to climate change on the map: A review of approaches, benefits, and risks. Sustainability Science, 6(2), 177-202. https://doi.org/10.1007/s11625011-0129-1

Ricketts, T.H., Dinerstein, E., Olson, D., Loucks, C. J., Eichbaum, W., DellaSala, D., Kavanagh, K., Hedao, P., Hurley, P. T., Carney, K. M., Abell, R., \& Walters, S. (1999). Terrestrial Ecoregions of North America: A Conservation Assessment. (b). Island Press.

Ricketts, Taylor H, Dinerstein, E., Olson, D. M., \& Loucks, C. (1999). Who' s Where in North Patterns of species richness and the utility of indicator taxa. Bioscience, May.

Rosenzweig, M. L. (1995). Species Diversity in Space and Time. Cambridge University Press, Cambridge, UK. 
Scott, D. F., \& Van Wyk, D. B. (1990). The effects of wildfire on soil wettability and hydrological behaviour of an afforested catchment. Journal of Hydrology, 121(1-4), 239-256. https://doi.org/10.1016/0022-1694(90)90234$\mathrm{O}$

Semeraro, T., Mastroleo, G., Aretano, R., Facchinetti, G., Zurlini, G., \& Petrosillo, I. (2016). GIS Fuzzy Expert System for the assessment of ecosystems vulnerability to fire in managing Mediterranean natural protected areas. Journal of Environmental Management, 168, 94-103. https://doi.org/10.1016/j.jenvman.2015.11.053

Shlisky, A., Waugh, J., Gonzalez, P., Gonzalez, M., Manta, M., Santoso, H., Alvarado, E., Ainuddin, A., Rodríguez-trejo, D. A., Swaty, R., Schmidt, D., Kaufmann, M., Myers, R., Alencar, A., Kearns, F., Johnson, D., Smith, J., \& Zollner, D. (2007). Fire, ecosystems and people: threats and strategies for global biodiversity conservation. The Nature Conservancy Global Fire Initiative Technical Report, 17. http://mrcc.isws.illinois.edu/living_wx/wildfires/fire_ecosystems_and_people.pdf Solomon, S. (2007). IPCC (2007): Climate change the physical science basis. AGUFM.

Turner, B. L., Kasperson, R. E., Matsone, P. A., McCarthy, J. J., Corell, R. W., Christensene, L., Eckley, N., Kasperson, J. X., Luers, A., Martello, M. L., Polsky, C., Pulsipher, A., \& Schiller, A. (2003). A framework for vulnerability analysis in sustainability science. Proceedings of the National Academy of Sciences of the United States of America, 100(14), 8074-8079. https://doi.org/10.1073/pnas.1231335100

Williams, L. R. R., \& Kapustka, L. A. (2000). Ecosystem vulnerability: A complex interface with technical components. Environmental Toxicology and Chemistry, 19(4 II), 1055-1058. https://doi.org/10.1002/etc.5620190435

World Wildlife Fund. (2006). WildFinder: Online database of species distributions. 


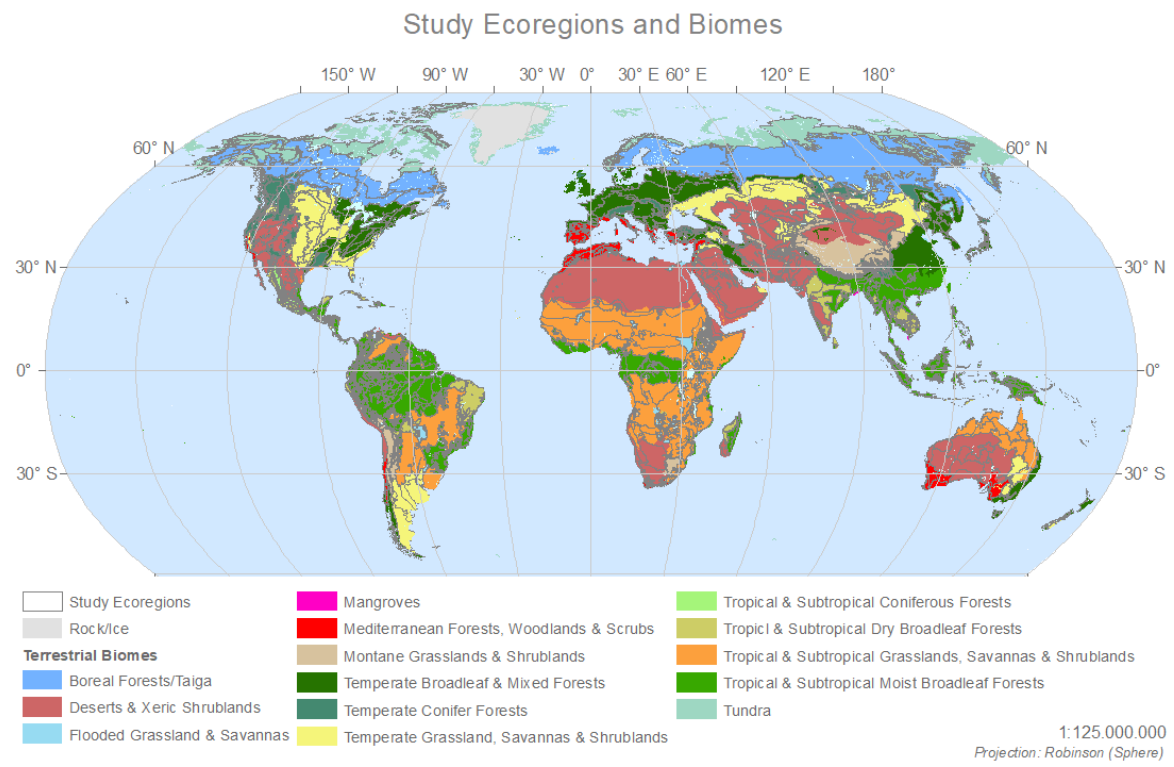

Figure A1: Terrestrial ecoregions within their respective biomes for this study. (Source: The authors).

\section{Biological Distinction}

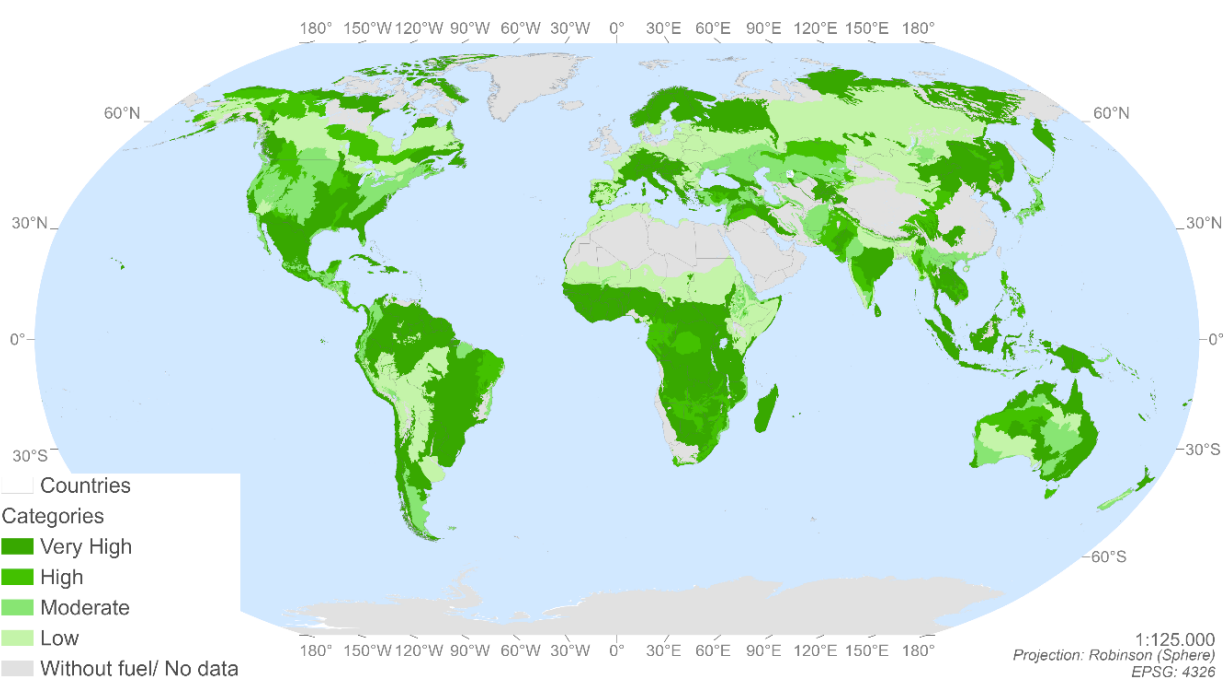

Figure A2: Spatial distribution by ecoregion of the Ecosystem Biological Distinction Value prepared by ecoregion evaluated within the biome to which they belong. (Source: The authors). 


\section{Conservation status}

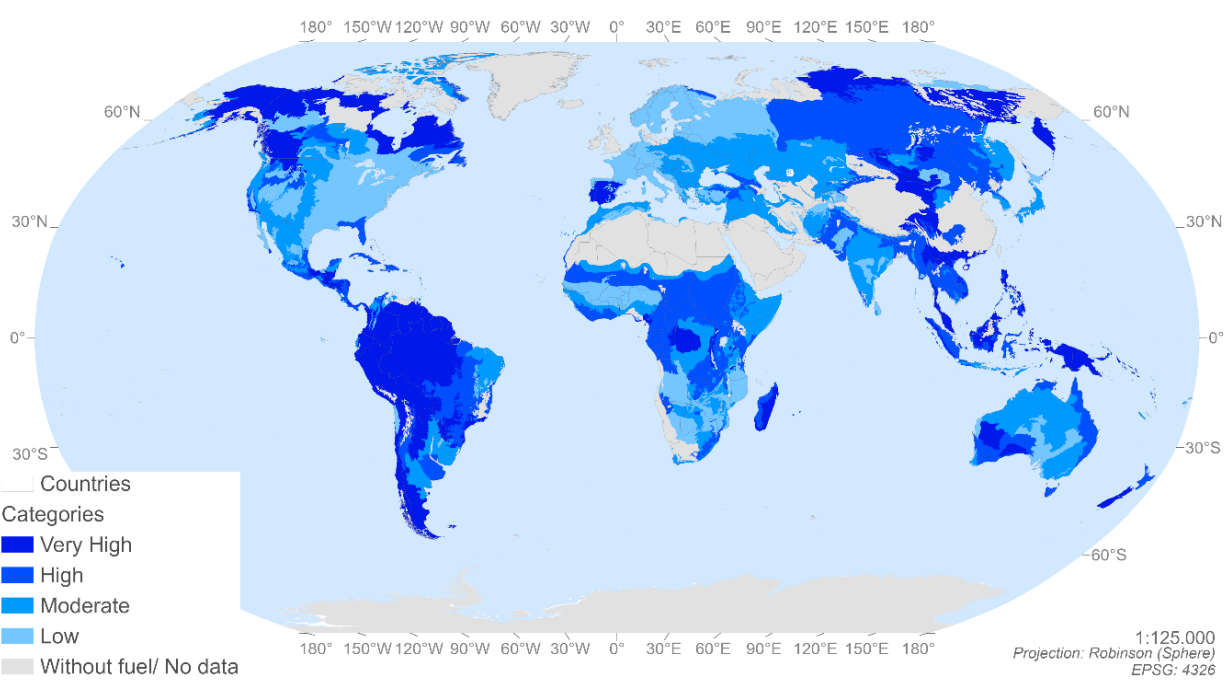

Figure A3: Spatial distribution by ecoregion of the Ecosystem Conservation Status Value produced by combining the Indices for Unique Habitats Preservation, Intact Forest Landscapes, Degree of Fragmentation and Degree of Protection. (Source: the authors)

\section{Adaptation to Fire}

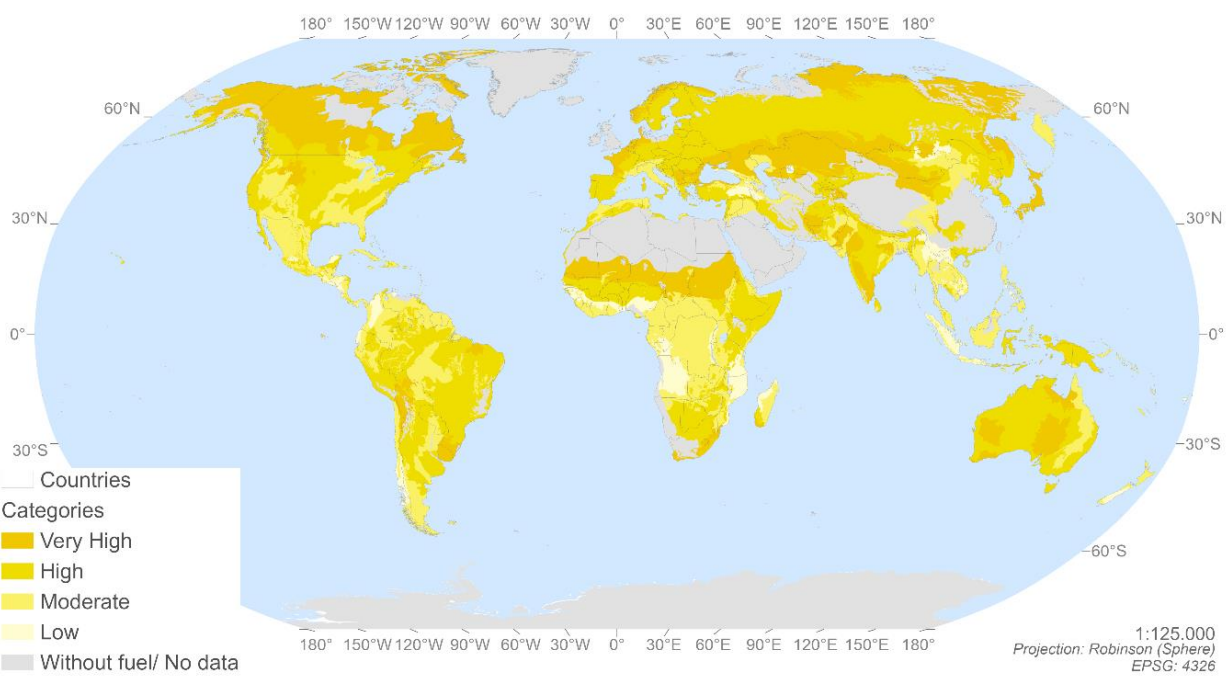

Figure A4: Spatial distribution by ecoregion of the Ecosystem Adaptation to Fire Value produced by combining the Fire Regime and its degree of alteration. (Source: The authors). 
https://doi.org/10.5194/nhess-2021-285

Preprint. Discussion started: 13 October 2021

(c) Author(s) 2021. CC BY 4.0 License.

Potential Soil Erosion

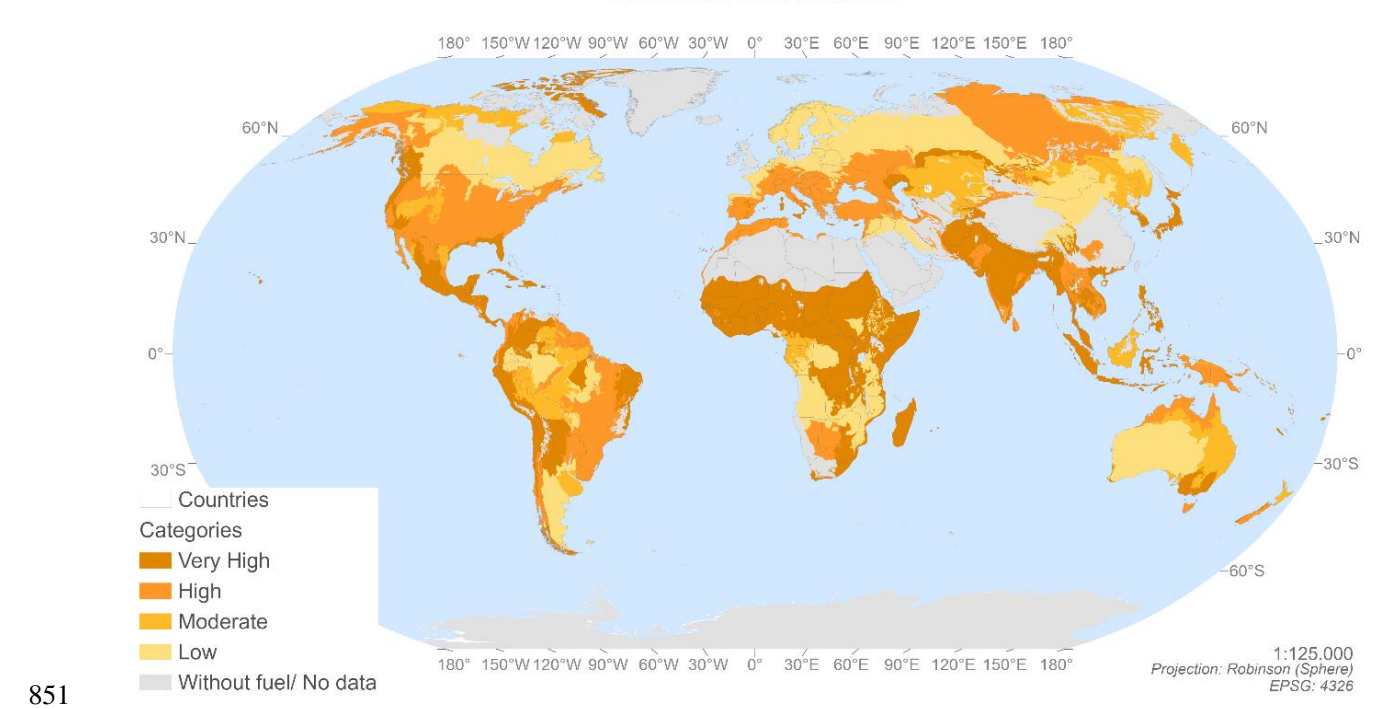

852

Figure A5: Spatial distribution of Potential Soil Erosion values by ecoregion resulting from the application of the FAO criterion for water erosion. (Source: The authors).

854 